PAPERS IN PHYSICAL OCEANOGRAPHY AND METEOROLOGY

PUBLISHED BY

MASSACHUSETTS INSTITUTE OF TECHNOLOGY AND

WOODS HOLE OCEANOGRAPHIC INSTITUTION

\title{
THE OCEANOGRAPHY
}

$\mathrm{OF}$

\section{THE NEW YORK BIGHT}

Vol. XII, No. 1

BY

BOSTWICK H. KETCHUM, ALFRED C. REDFIELD

AND

JOHN C. AYERS

Contribution No. 549 from the Woods Hole Oceanographic Institution

CAMBRIDGE AND WOODS HOLE, MASSACHUSETTS

AugusT, 1951 
TABLE OF CONTENTS

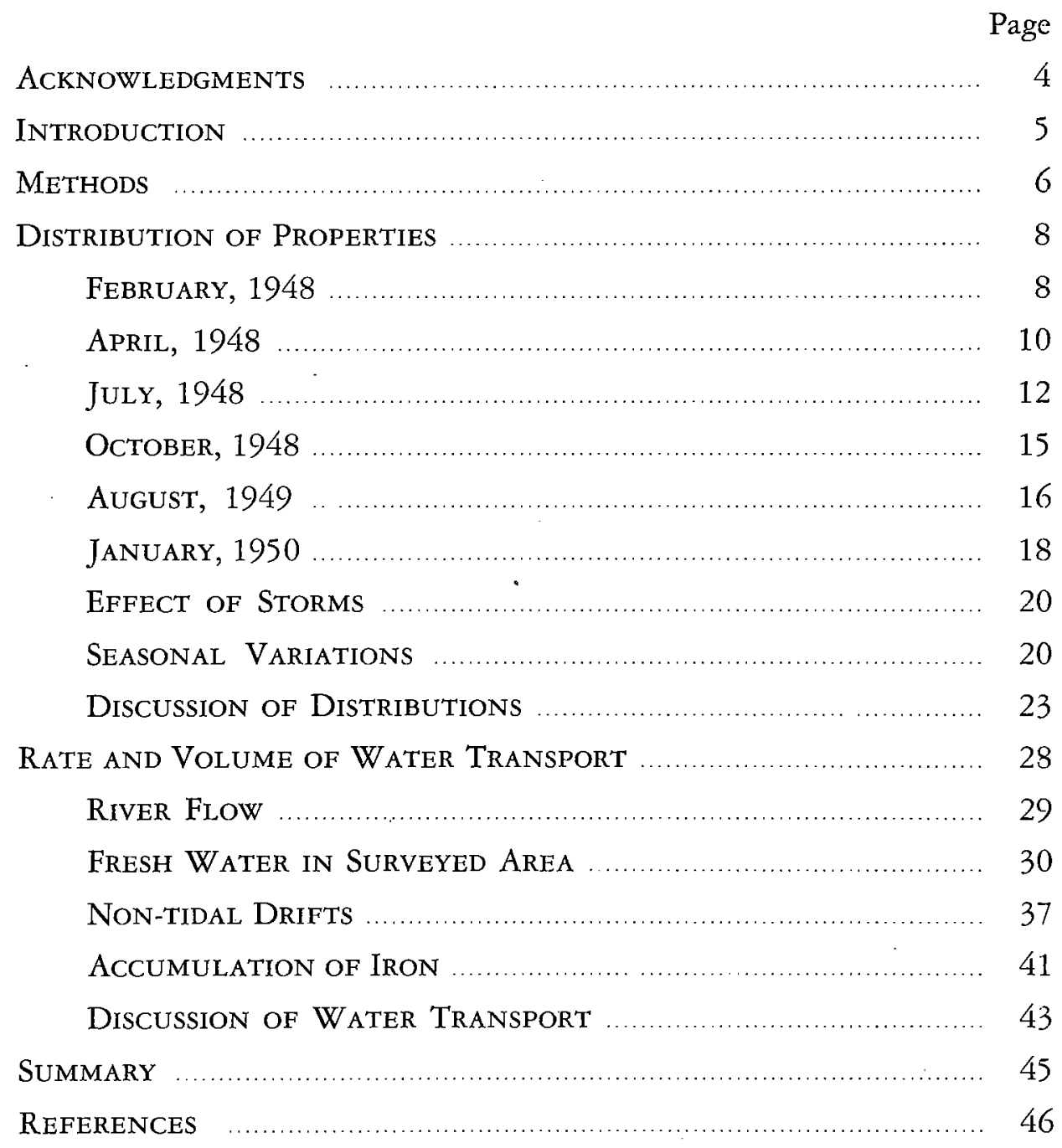




\section{ACKNOWLEDGMENTS}

This investigation was supported, in part, by a grant from The National Lead Company, administered by the Committee for the Investigation of Waste Disposal of the Division of Biology and Agriculture of the National Research Council.

The authors gratefully acknowledge the cooperation received from the Officials of The National Lead Company, especially Mr. D. W. Robertson, Mr. A. V. Bender and Mr. John Lloyd. Dr. Wm. L. Ford supervised the chemical procedures, and was a member of the group during the first three cruises. Miss D. Jean Keen has done most of the tedious planimetry of cross sections required for the evaluation of the rate and volume of water transport. The U. S. Fish and Wildlife Service made the final cruise possible by supplying the facilities of their Research Vessel, Albatross 1II. The authors also thank the several scientific observers who assisted on the cruises, and the officers and crews of the Balanus, Caryn and Albatross III. 


\section{INTRODUCTION}

The New York Bight consists of the waters lying between Cape May, New Jersey, and Montauk Point, Long Island. A portion of the general southwesterly current known as the Coastal Drift lies in the seaward part of the Bight. Inshore from the Coastal Drift is an area of complex hydrography where the combined outflows of the Hudson River and other rivers enter the sea.

In the region where the New Jersey and Long Island coastlines converge, an area 25 nautical miles on each side has been studied at all seasons of the year. This area extends from Sandy Hook southward to a point off Seaside Heights, eastward to $73^{\circ} 15^{\prime} \mathrm{W}$ longitude, north to the Long Island shore, and westward to Rockaway Inlet (Figure 1).

The depth of water in the area averages about 90 feet, except in the innermost part of the Hudson Canyon which runs roughly northwest-southeast across most of the survey area. In the Canyon, depths in excess of 240 . feet are found within the limits of the area studied.

The hydrographic conditions in the area are in essence similar to those off the mouths of other large rivers. The combined flows of the Hudson and other rivers entering the surveyed area discharge enough fresh water annually to replace about one-half of the total volume of water under the 600 square miles of sea surface extensively surveyed. The sa. linity within the area is nearly as high as that of adjacent coastal water, however, and the actual quantity of river water within the area at any time rarely exceeds one percent of the total volume of water. Quantitative evaluation of these factors has led to the conclusion that there is an active circulation within the area which rapidly disperses the introduced river effluent.

Many surveys of coastal and estuarine waters have been made. Outstanding among these are the survey of the River Tees, $(1931,1935)$, of the Tamar Estuary, (Hartley and Spooner, 1938; Milne, 1938), and of Alberni Inlet, (Tully, 1949). The general principles of estuarine circulations may be summarized as follows: In order to remove the added river water there must be a non-tidal drift of mixed water in a net seaward direction. When river flow remains constant, a steady state distribution of fresh and salt water throughout the estuary is attained, and at such times the net transport of river water seaward through any complete cross section of the estuary exactly equals the contribution of fresh water from the river during the same interval of time. As the mixture containing the river water moves seaward it gets progressively more saline, as additional sea water is entrained. In order to provide this sea water there must be a counter drift having a net flow in a landward direction.

Superimposed on these necessary parts of the circulation are tidal and wind currents. The velocities of the tidal currents are commonly much greater than the velocity of the non-tidal drift, making the latter difficult to measure directly. It can be inferred, however, from the distribution of river water, as derived from the salinity distribution. Using the river water in this way we have evaluated the exchanges of the waters within the New York Bight. Tully (1949) has analyzed the circulation in Alberni Inlet by similar methods. 
Tidal current measurements made by the Coast and Geodetic Survey at various locations in the northwestern corner of the surveyed area are summarized by Marmer (1935). At Scotland Lightship, which is the location of the stations at the western end of Section $A$ in Figure 1, the total excursion which results from the flood or ebb tidal currents is less than two miles. The currents at Ambrose Lightship, about five miles to the eastward, produce displacements only about half as great. The tidal displacements throughout the rest of the area are presumed to be less than these. The pattern of distribution of properties will be displaced, therefore, a distance less than \pm 1 mile at various stages of the tide. This distance is small in comparison to the size of the area surveyed, especially when considering the fact that distances between stations ranged from 5 to 8 miles. It was unnecessary, therefore, to attempt to take comparable stations at similar stages of the tide.

Other considerations, beside its interesting hydrography, have contributed to the choice of this area for study. Because it is adjacent to centers of dense population and heavy industrial concentration, the New York Bight serves the conflicting purposes of waste disposal and recreation.

Sewer effluents and industrial wastes enter the area by way of the rivers. Sewage sludges are barged out and dumped within the region studied. During the period covered by our surveys, The National Lead Company commenced operations to barge and discharge at sea the waste from its titanium plant at Sayreville, New Jersey. Since iron was a major constituent of this waste, analyses for iron in the water were made at each station, and the results have been valuable in checking the rate of the circulation which was computed from the distribution of river effluent.

The New York Bight is also used extensively for recreational purposes. Because the area is readily and cheaply accessible by public transportation it must serve the recreational demands of a large part of the population of metropolitan New York. Sport fishing, bathing and boating are the principal recreational activities. Small but valuable commercial fisheries for shellfish and fin-fish also exist.

The purpose of this study was to investigate the hydrographic processes in the New York Bight since they have an important bearing on the general problems of coastal oceanography and a knowledge of them should lead to a more successful evaluation and utilization of the area for the diverse purposes it must serve.

\section{METHODS}

Seven cruises have been made for the survey of the area. The dates, the areas surveyed, and the station numbers are given in Table I. Additional stations were taken for special purposes on several of the cruises. The February, March and April surveys combine observations obtained on several different days. On the other four cruises all of the stations were occupied within a period of 24 to 30 hours.

The hydrographic stations were arranged in a rectangular grid, so that four or five east-west sections were made across the area with stations on each about 5 miles apart. Additional stations, more widely spaced, were made south of the grid on the August, 1949, and the January, 1950, cruises. The locations of the stations and section lines are shown on Figure 1. 
VOL. XII, NO. 1. THE OCEANOGRAPHY OF THE NEW YORK BIGHT

TABLE I

List of Hydrographic SURveYs of the New YORK Bight

Date

Feb. 2-19, 1948

Mar. 12-Apr. 4, 1948

Apr. 20-30, 1948

July 22-31, 1948

Oct. $21-29,1948$

Aug. 16-23, 1949

Jan. $4-6,1950$
Vessel

BALANUS

"

$"$

CARYN

",

ALBATROSS III

Cruise
No.

18
19
20
22
4
12
30

Area
Surveyed
sq. miles

Hydrographic Station Nos.
$82-103$

$104-121$

$122-140$

141-161

14-31

56-102

$1-37$

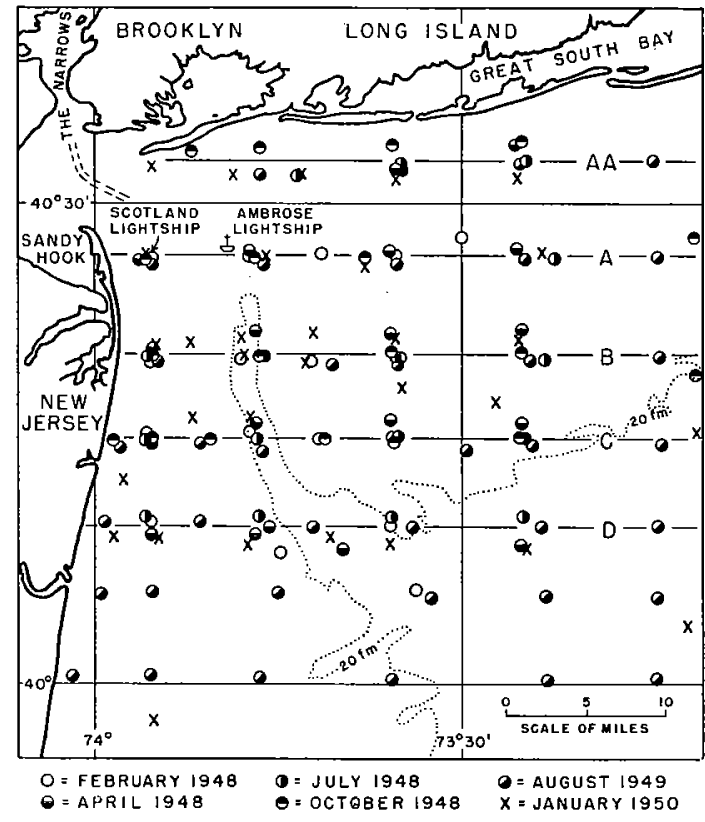

Fig. 1. Locations of stations occupied during various cruises.
Nansen bottle samples, and reversing thermometer temperatures were obtained at 10 meter depth intervals, except at the shallowest stations where 5-meter intervals were used. The water samples were analyzed for salinity, oxygen and iron. Salinity was determined by silver nitrate titration according to Oxner's description of Knudsen's method (1920). Oxygen content was obtained by the Winkler method, oxygen saturation by Kalle's nomograph (1939), and iron by the method of Cooper (1935), and use of the electric eye photometer (Ford, 1950).

In measuring the iron a turbidity reading was taken in the photometer after the acidification, but before the addition of the dipyridyl reagent. This turbidity reading was subtracted from the reading obtained in the final analysis. The turbidity correction introduced some uncertainty in the analysis, especially when the iron concentration was small (less than $10 \mu \mathrm{g} / 1)$.

The oxygen and iron analyses were made on shipboard as soon as possible after the collection of the samples. During the October cruise it was impossible to do the iron analyses aboard, so the samples were stored in Polythene plastic bottles and the analyses were completed within two weeks.

During each cruise continuous records of surface temperature and salinity were obtained by means of the salinity-temperature-depth (STD) recorder (Jacobson, 1948; Ford, 1949). These records have made possible the exact positioning of surface contours of salinity, temperature, and density along the course of the ship. At each station, the measuring element was lowered to the bottom to obtain a continuous record of the vertical distribution of temperature and salinity. The vertical temperature distribution was also obtained by bathythermograph lowerings both on stations and halfway between stations.

The surface record of salinity and temperature was corrected to agree with a bucket temperature and surface salinity water sample taken at the time of each bathythermograph 

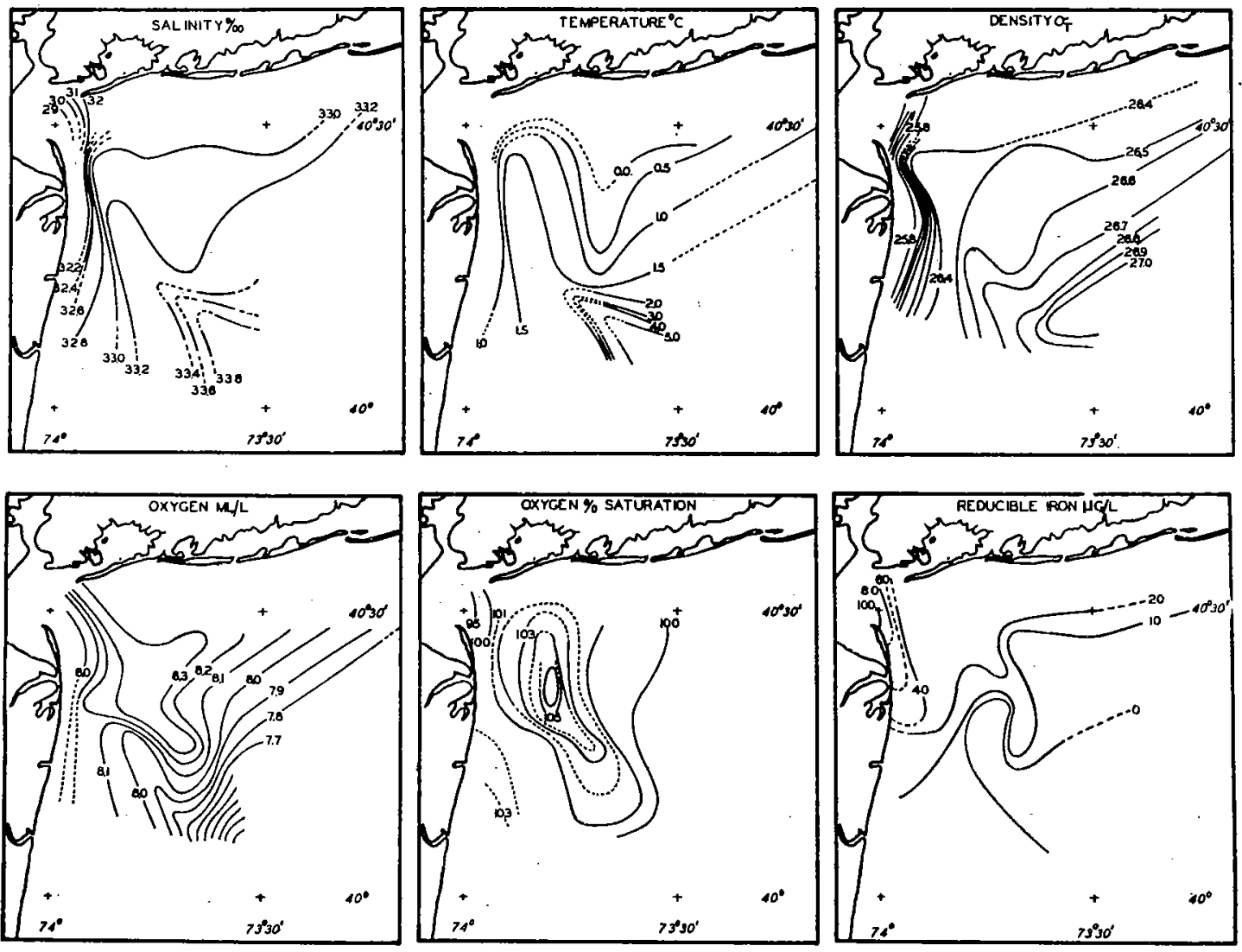

Hig. 2. Surface distribution of properties in February, 1948.

lowering. At the stations the STD record was corrected to the Nansen bottle salinity and reversing thermometer temperature at each depth. The necessity of correcting the STD record at various depths is emphasized when there are vertical temperature gradients, since the salinity correction may be quite different at different temperatures. The corrected curves thus obtained retain the detailed structure inherent in the continuous record. This detail is essential in order to obtain accurate results in calculating the total quantity of river water in the area.

\section{DISTRIBUTION OF PROPERTIES \\ February, 1948}

The distribution of properties observed in February, 1948, on Balanus Cruise 18, are shown in Figures 2 and 3. The brackish water containing the effluent of the rivers, characterized by low salinities $\left(29\right.$ to $32.8 \%$ ), and low temperatures $\left(-1.0\right.$ to $+1.0^{\circ} \mathrm{C}$ ), was found mainly in a narrow band, about 5 miles wide, along the New Jersey coast. A tongue of more saline and warmer water, protruding northward from offshore, was found immediately east of this band of freshened water. A bulge of slightly freshened, colder water extended from Long Beach, Long Island, for a distance of about 20 miles southward. At this time of year these different bodies of water appeared to occupy, in their respective areas, the entire depth of the water column. The water along the eastern side of the surveyed area 

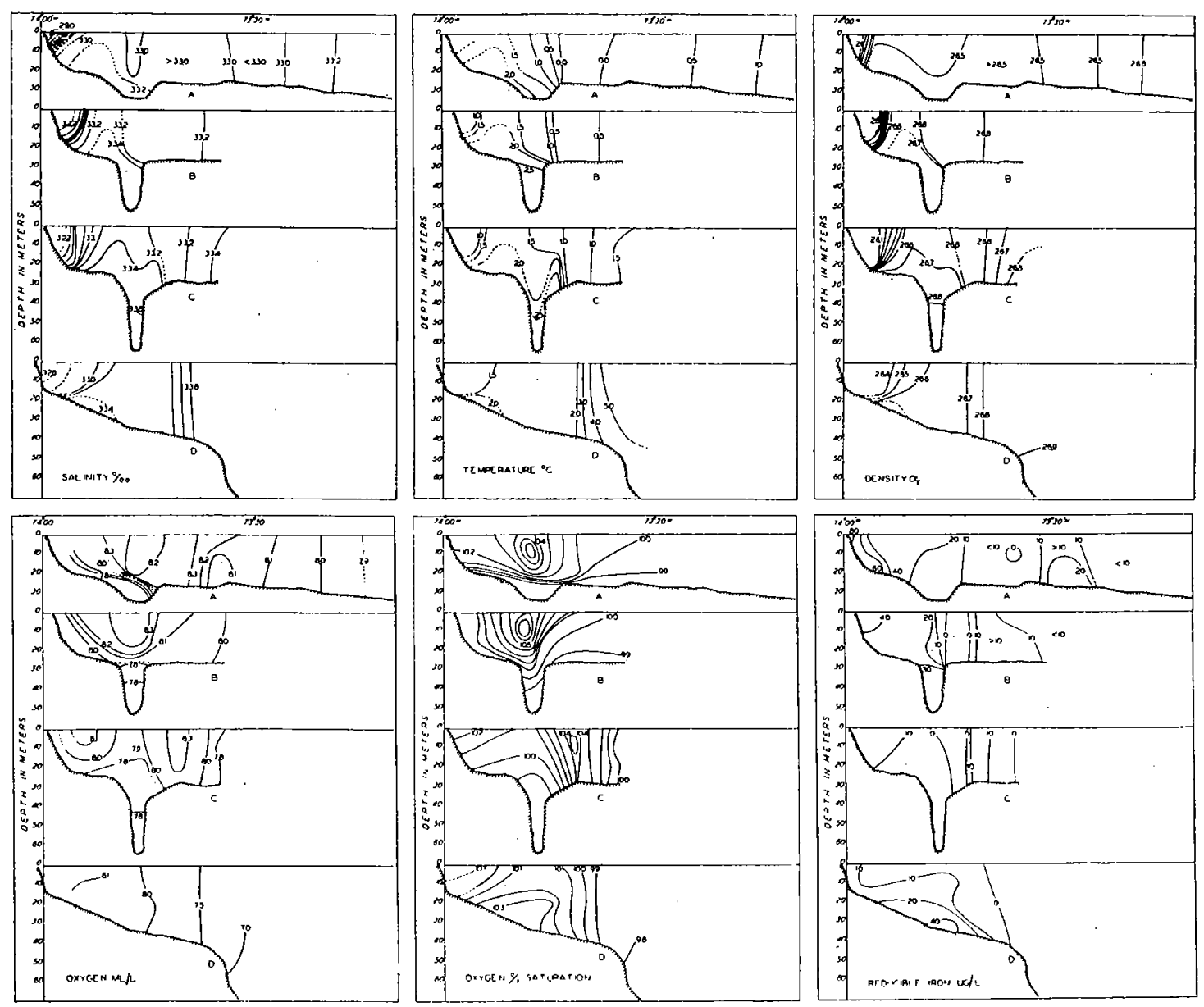

Fig. 3. Vertical distribution of properties in February, 1948. The vertical distortion in this, and in subsequent comparable figures, is about $1: 400$.

was quite uniform in all its properties and was characteristic of the inshore coastal water at this time of year (Bigelow, 1933).

In the northwestern and in most of the central part of the area the surface water was slightly supersaturated with oxygen, and this supersaturation extended to variable depths in the water column. Throughout the remainder of the area the water was between 98 and $100 \%$ saturated. No close relation between the distribution of salinity, temperature and oxygen was apparent.

The concentration of reducible iron was greatest in the mouth of New York Lower Bay where the iron-contaminated river waters emerge. Iron concentrations of $142 \mu \mathrm{g} / 1$ were found in Sandy Hook Channel, and water containing $40 \mu \mathrm{g} / 1$ extended about 12 miles southward from Sandy Hook. The water high in iron thus occupied the same general area as the low salinity water. Water containing no detectable amount of iron was found in the southeastern part of the area, and this low-iron water intruded as a tongue from the southeastern corner toward the south central part of the area. In the western part of the most southerly section (D) the iron concentrations increased from the surface 

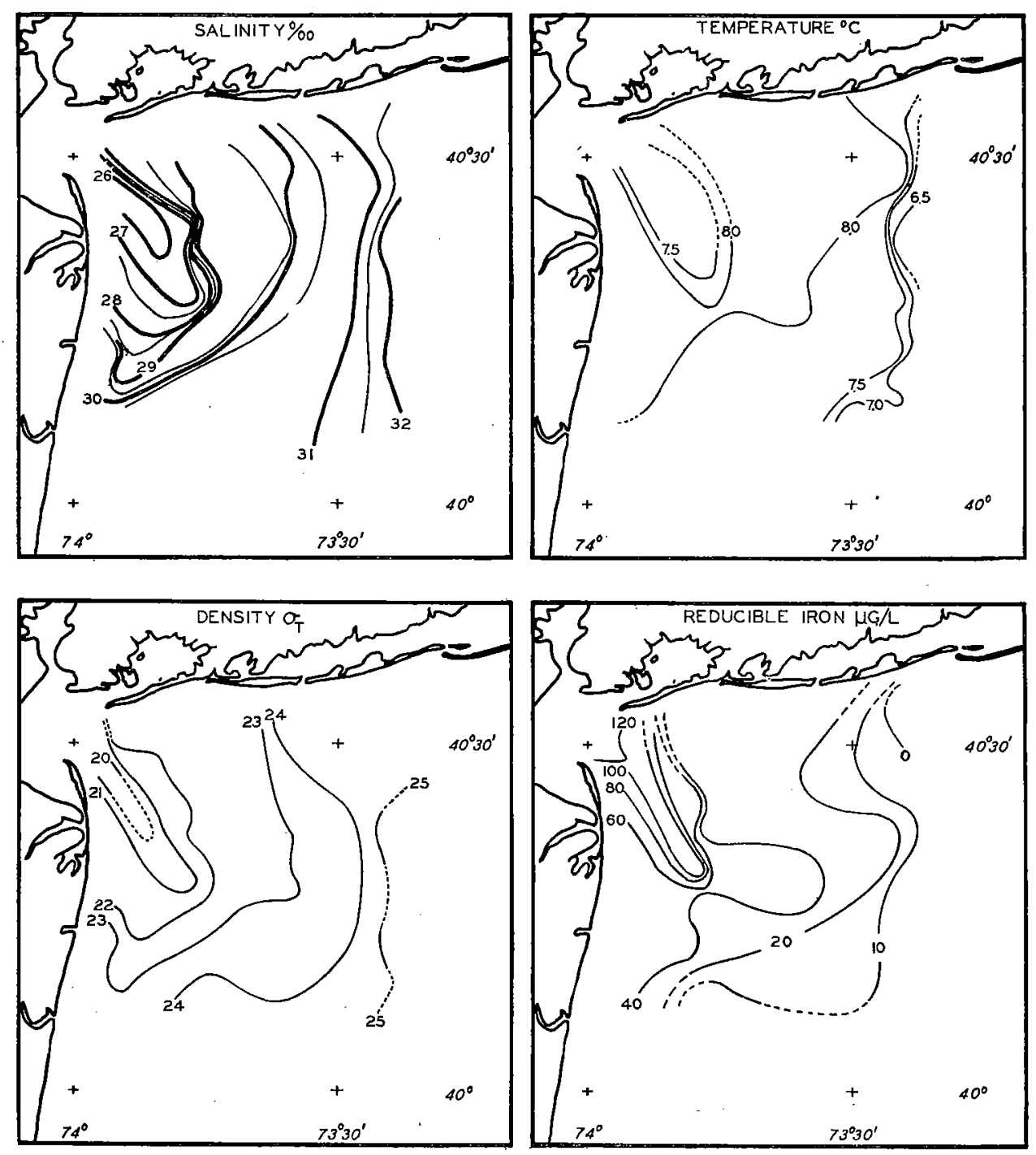

Fig. 4. Surface distribution of properties in April, 1948.

to the bottom. Similar, but smaller, increases were observed in the deep parts of the Hudson Canyon. The iron concentrations observed greatly exceed the solubility of iron in sea water (Cooper, 1937) and this type of distribution may reflect the settling of the oxides of iron.

\section{April, 1948}

The distribution of properties observed in April, 1948, on Balanus Cruise 20, shown in Figures 4 and 5, reflect the greatly increased river flow occurring at this time (see Table IV, discussed below). The principal differences between the February and April conditions are found in the marked freshening and warming of the water, and in the wider spread of freshened water over the surface with the associated development of vertical gradients of salinity and temperature. 

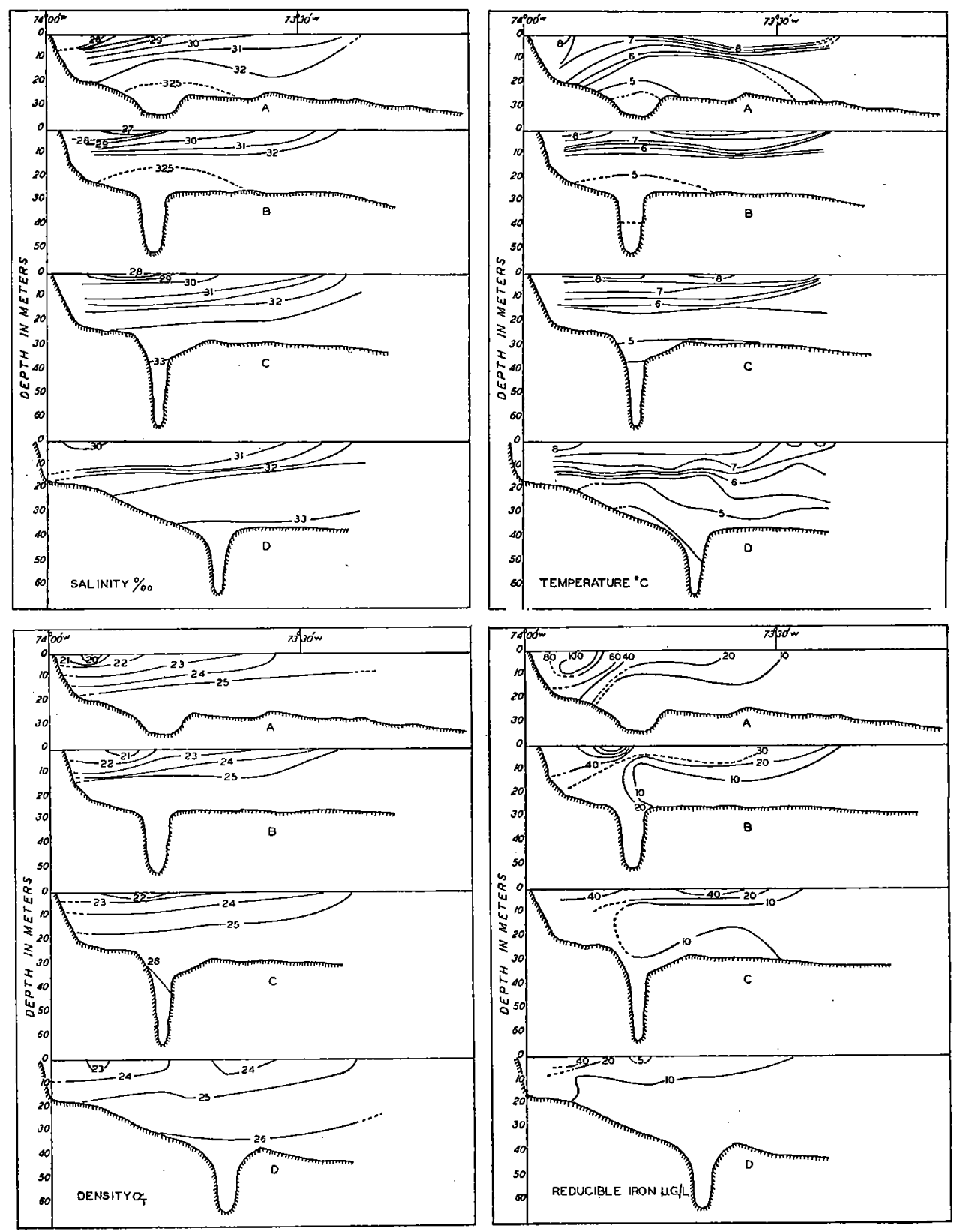

Fig. 5. Vertical distribution of properties in April, 1948.

A tongue of diluted water, characterized by salinities of 26.0 to $30.0 \%$, and temperatures of less than $8^{\circ} \mathrm{C}$, intruded from the river mouth toward the center of the area. This tongue extended to as much as 12 miles off the New Jersey coast, and the freshest water was separated from the coast by more saline water. In vertical distribution the salinity was characterized by gradients at all stations. In no section did any one isohaline reach both the surface and the bottom. The freshest water in each section lay in a shallow 

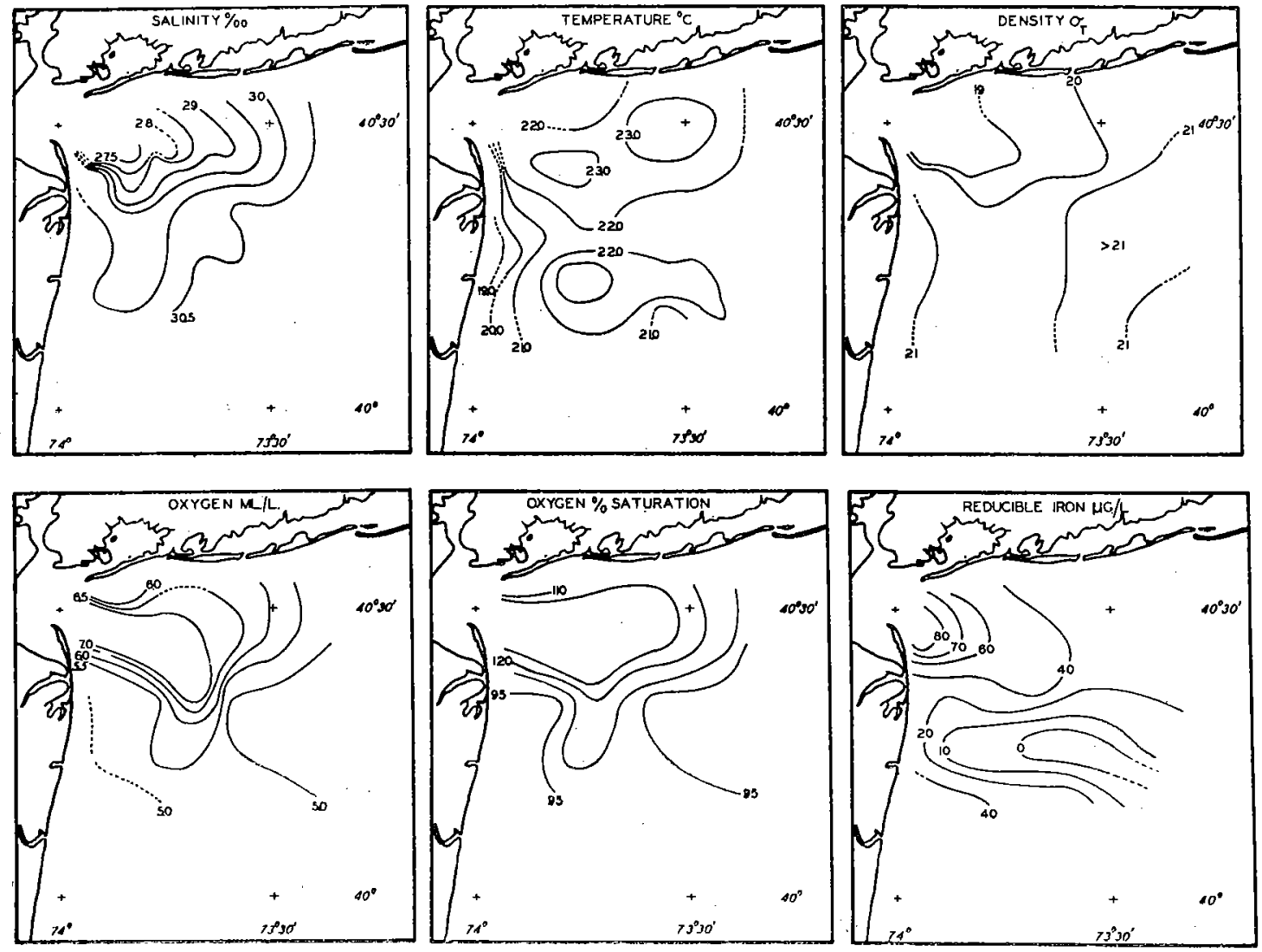

Fig. 6. Surface distribution of properties in July, 1948.

trough in the west-central part of the area, and the more saline water adjacent to the New Jersey coast was continuous, at subsurface depths, with surface water to the eastward.

There were measurable amounts of reducible iron in the surface water in all parts of the area except the northeast corner. Iron concentrations of 120 to $180 \mu \mathrm{g} / 1$ were found in the mouth of Lower New York Bay, and a tongue of water containing large but gradually decreasing amounts of iron extended from the northwest corner toward the center of the area. This tongue occupied the same location as the diluted water containing the river effluent. Most of the area was occupied by surface water containing 10 to $40 \mu \mathrm{g} / 1$ of iron.

The bottom water throughout the eastern parts of the area contained from 0 to $10 \mu \mathrm{g} / 1$ iron. In Sections A, B, and D, water containing small iron concentrations extended westward along the bottom to the center of the area. In Section $C$ this water extended westward, but at mid-depth, with the deeper water containing higher concentrations. At the western ends of the sections the iron generally decreased toward the bottom.

No oxygen samples were taken during the April cruise.

$$
\text { July, } 1948
$$

The distribution of properties observed in July, 1948, on Balanus Cruise 22, are shown in Figures 6 and 7. These distributions are characterized by the further freshening of the 

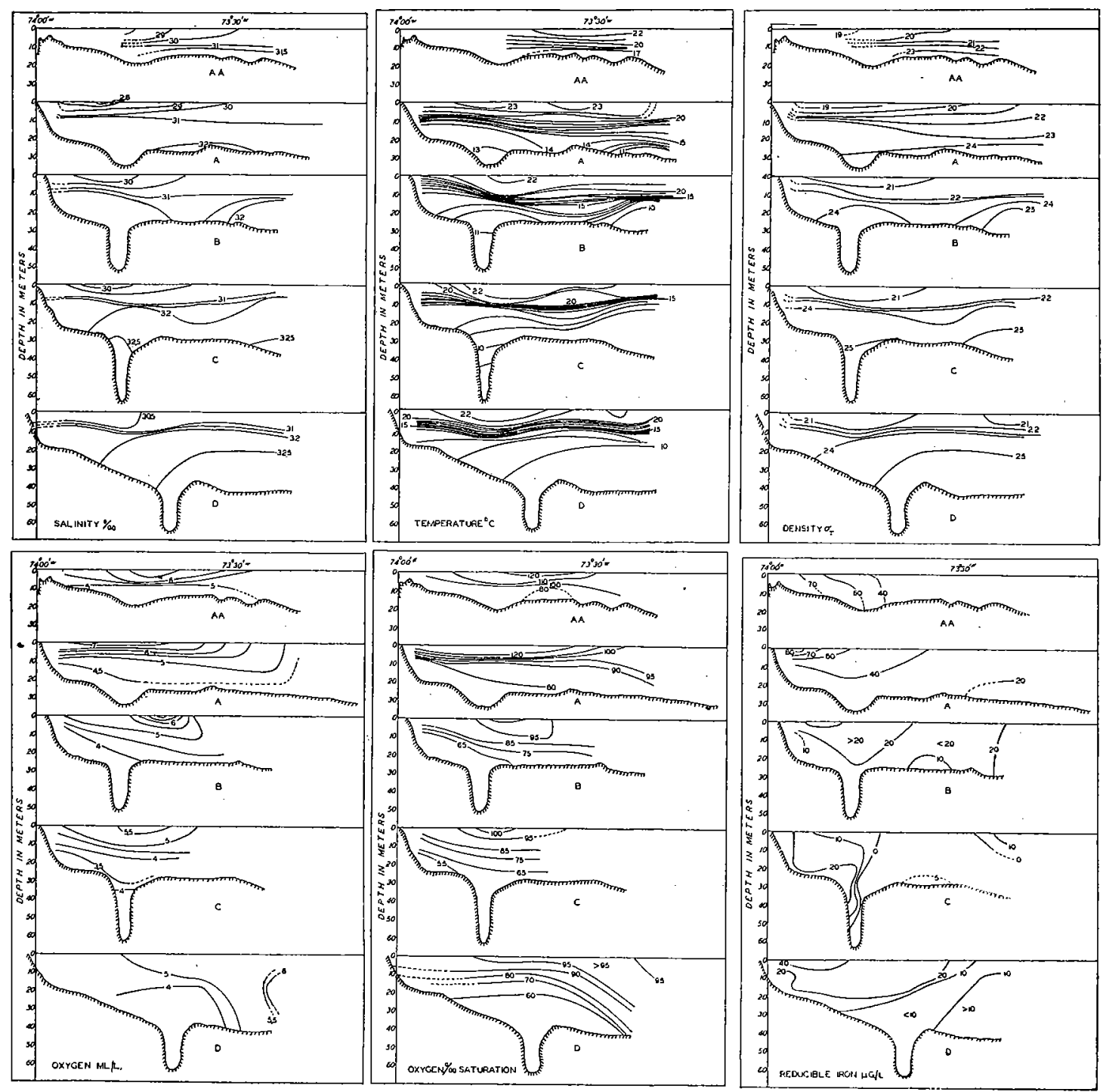

Fig. 7. Vertical distribution of properties in July, 1948.

entire area, greater lateral spread of the freshened surface water, and more intense vertical gradients of salinity and temperature.

The freshened water, having salinities ranging from 27.5 to $30.5 \%$, was limited to the upper 30 feet, and spread from New York Lower Bay in a double-lobed tongue extending over most of the area. It appears that part of the river effluent was escaping to the eastward along the Long Island shore, and part extended southward in a rather narrow band lying over the west bank of the Hudson Canyon, and over the Canyon itself. This effluent was separated from the New Jersey shore by a band of more saline water about 10 miles wide. The freshest water in each section was found in shallow, lens-shaped areas, underlain by a zone of mixed water which extended to a depth of about 30 feet. Below this depth the salinity of the water was greater than $31 \%$, and along each section the deeper water was continuous with the water of similar character to the eastward of the surveyed 

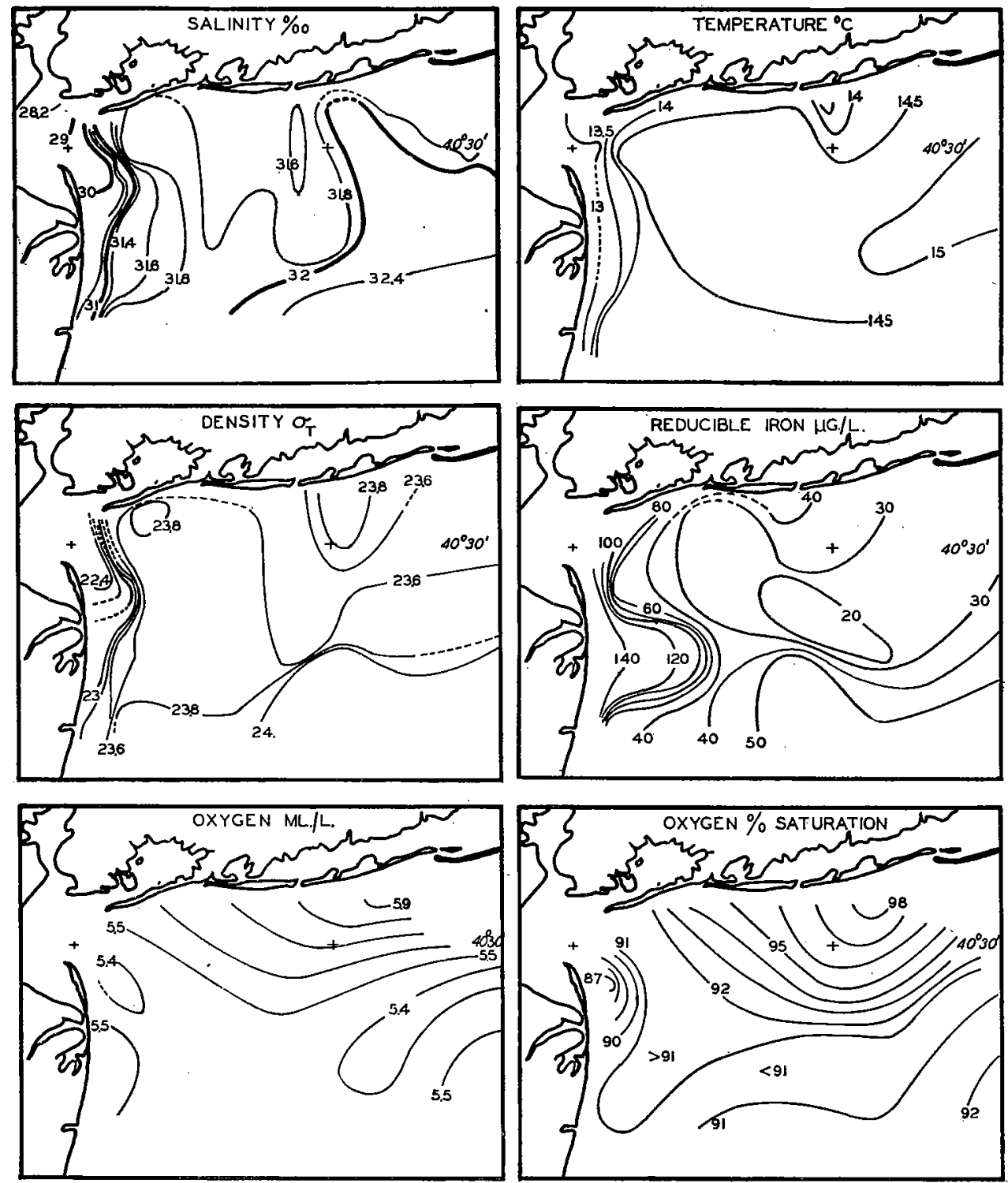

Fig. 8. Surface distribution of properties in October, 1948.

area. The most saline water $(32.5 \%$ ) was found in the deepest part of the Hudson Canyon and at the eastern ends of Sections $C$ and $D$.

The surface temperatures were seasonably high. Their distribution was not directly associated with that of salinity. The vertical temperature gradients were marked. Apparently the isolated patches of surface water of high temperature reflect local solar heating.

The oxygen content of the water in the northern half of the area was relatively high, reaching saturation values as great as $120 \%$. Over most of the southern part of the area the water was 95 to $100 \%$ saturated with oxygen. These high oxygen concentrations and supersaturations were limited to the upper 30 feet of the water column. The deeper water 

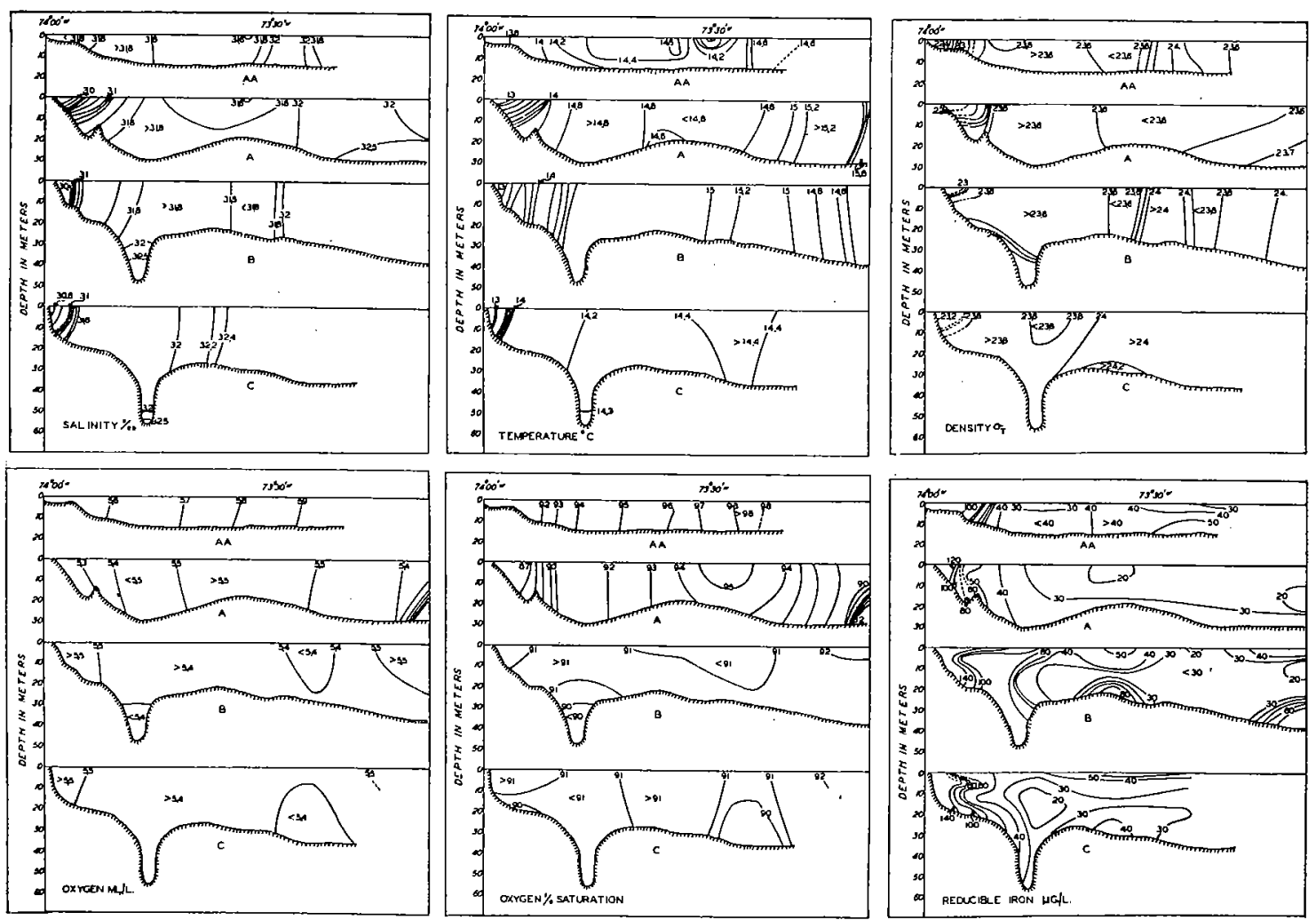

Fig. 9. Vertical distribution of propertues in October, 1948.

was undersaturated, with the degree of undersaturation increasing to the southward. Thus, in Sections AA and A, water of $80 \%$ saturation was found near the bottom, while throughout most of Section D the deeper water was less than $60 \%$ saturated. A small patch of water showing only $55 \%$ saturation was observed in the western end of Section C.

The iron content of the surface water in July ranged from $80 \mu \mathrm{g} / 1$ at Scotland Light to zero in the southeast corner. A tongue of iron-rich ( 40 to $80 \mu \mathrm{g} / 1$ ) water protruded from the mouth of Lower Bay toward the center of the area. From the southeast corner a broad tongue of water containing 0 to $20 \mu \mathrm{g}$ iron per liter extended westward nearly to the New Jersey coast.

In the deeper water the iron was most concentrated at the western ends of Sections AA and A. Several local concentrations greater than in the surface or in any adjacent water appeared at mid-depths in these sections. A wide band of water containing no iron occupied the eastern part of Section C, extending from surface to bottom. This water also occupied the bottom of the Canyon in this section. The distortion of the contours to the west of the Canyon in this section suggests that some of the iron had settled through the thermocline. The other sections do not contain any indications that the iron was settling.

October, 1948

The distribution of properties observed in October, 1948, on Caryn Cruise 4, are shown in Figures 8 and 9. This cruise was interrupted by a northerly storm with winds 

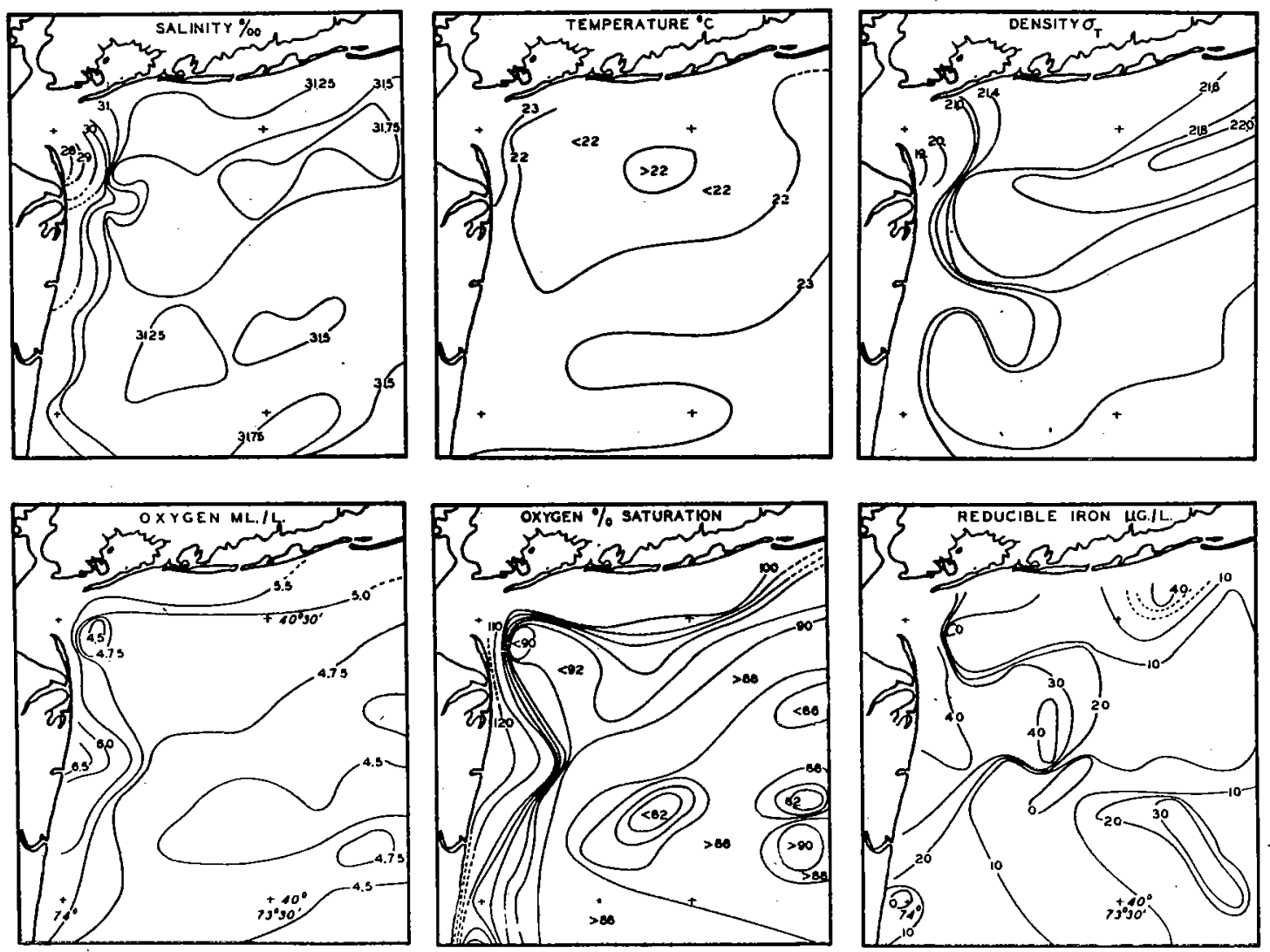

Fig. 10. Surface distribution of properties in August, 1949.

of $39 \mathrm{mph}$. velocity on October 24-25. The northern part of the area was surveyed before the storm, and the easternmost parts of Section A and Section B during the storm. On October 26 the surface conditions in the northwestern part were resurveyed, and the southern part of the survey was completed.

The freshest water $(29$ to $31 \%$ ) at this time occupied a band about 10 miles wide along the New Jersey coast. This water was also colder $\left(13\right.$ to $\left.14^{\circ} \mathrm{C}\right)$ and was less saturated with oxygen ( 87 to $91 \%$ ) than the water elsewhere. East of this band of freshened water, three tongues of more saline water $(>31.8 \%$ ) extended northward, two of them reaching the Long Island shore. Throughout the area the water was nearly homogeneous vertically in salinity, temperature and oxygen.

During the October cruise the iron content of the water was fairly high throughout the area, and no water of zero iron content was found. The concentrations in the freshened water along the New Jersey coast ranged from 60 to $>140 \mu \mathrm{g} / 1$. Vertical iron gradients were found at every station, with the concentration of iron generally increasing at or near the bottom.

\section{August, 1949}

The distributions observed in August, 1949, on Caryn Cruise 12 are shown in Figures 10 and 11. At this time the river flow was less than half of that during the previous July, 

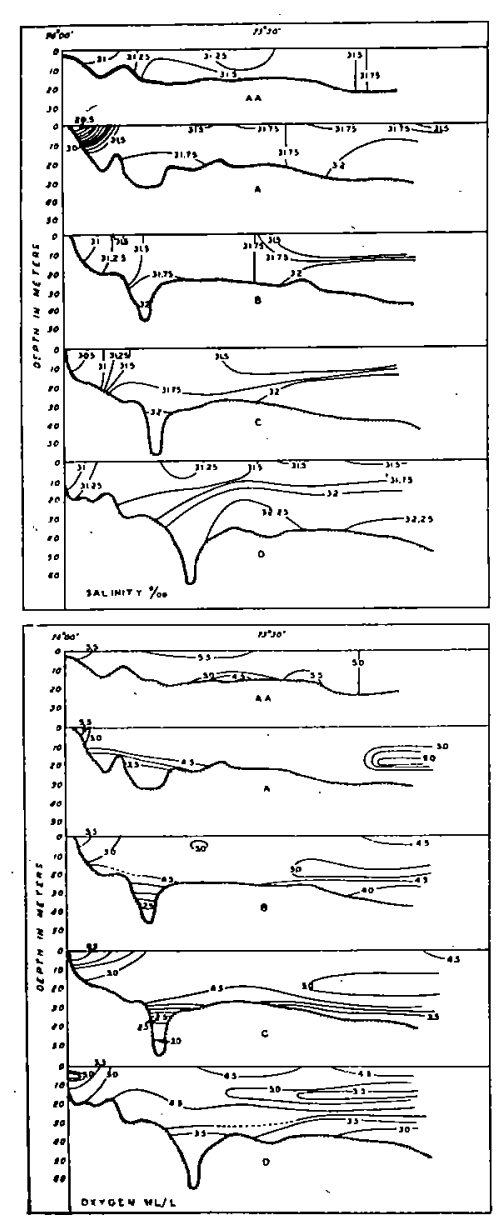
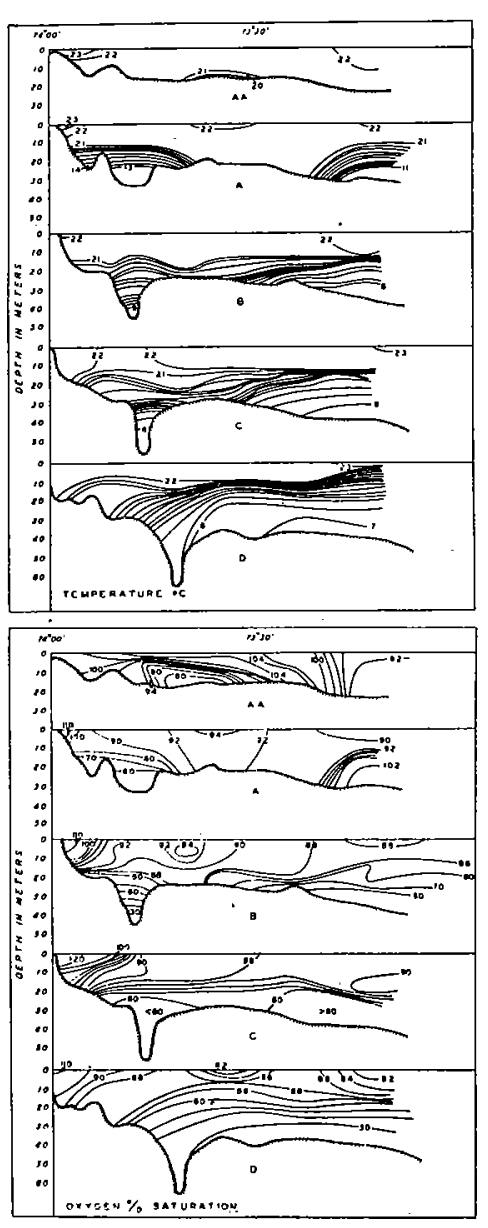
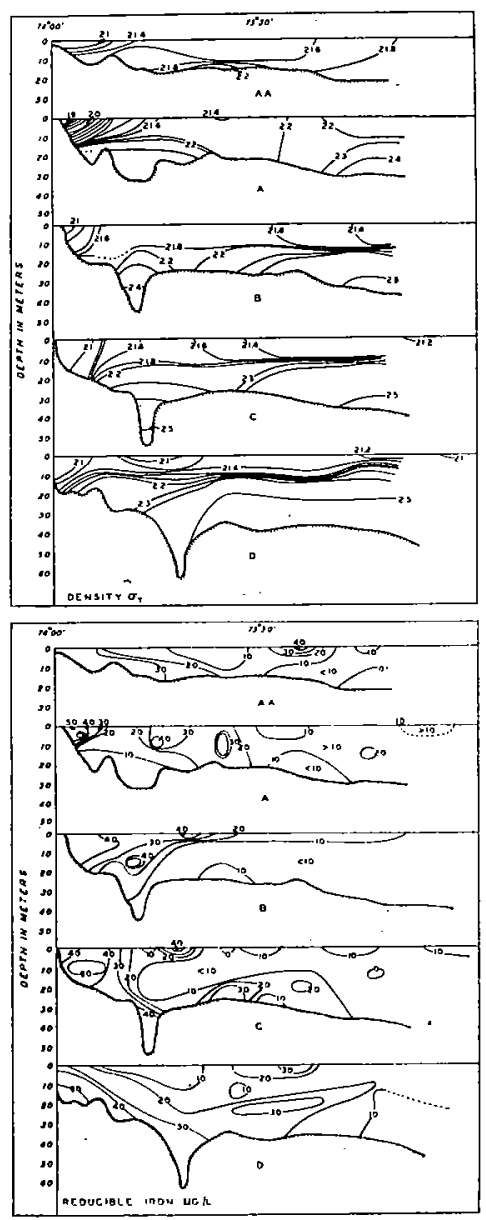

Fig. 11. Vertical distribution of properties in August, 1949.

and the salinity distribution reflects this difference, as comparison of the location and area enclosed by the $30 \%$ contour at the two periods will show.

In August, 1949, most of the river water was included in a band along the New Jersey shore, but discontinuous patches of water of variable salinity were found throughout the area. The vertical sections show that in some places there were vertical gradients of salinity, in others the water was homogeneous from surface to bottom. The vertically homogeneous water in Sections A and B, with salinities of $31.75 \%$, was continuous with subsurface water to the southward. The salinity distribution observed on this cruise does not show a clearly defined path for the escape of the river effluent, and suggests that the river had less influence in determining the circulation than during previous cruises.

The temperature was quite uniform over the surface throughout the area and to depths of 10 to 20 meters. Below this depth there was a rapid decrease in temperature, giving a pronounced thermocline at most stations. In Sections AA and A there was no temperature gradient between the surface and bottom in depths of less than 20 meters. This corresponded to the vertical homogeneity of salinity in the same location, though the temper- 

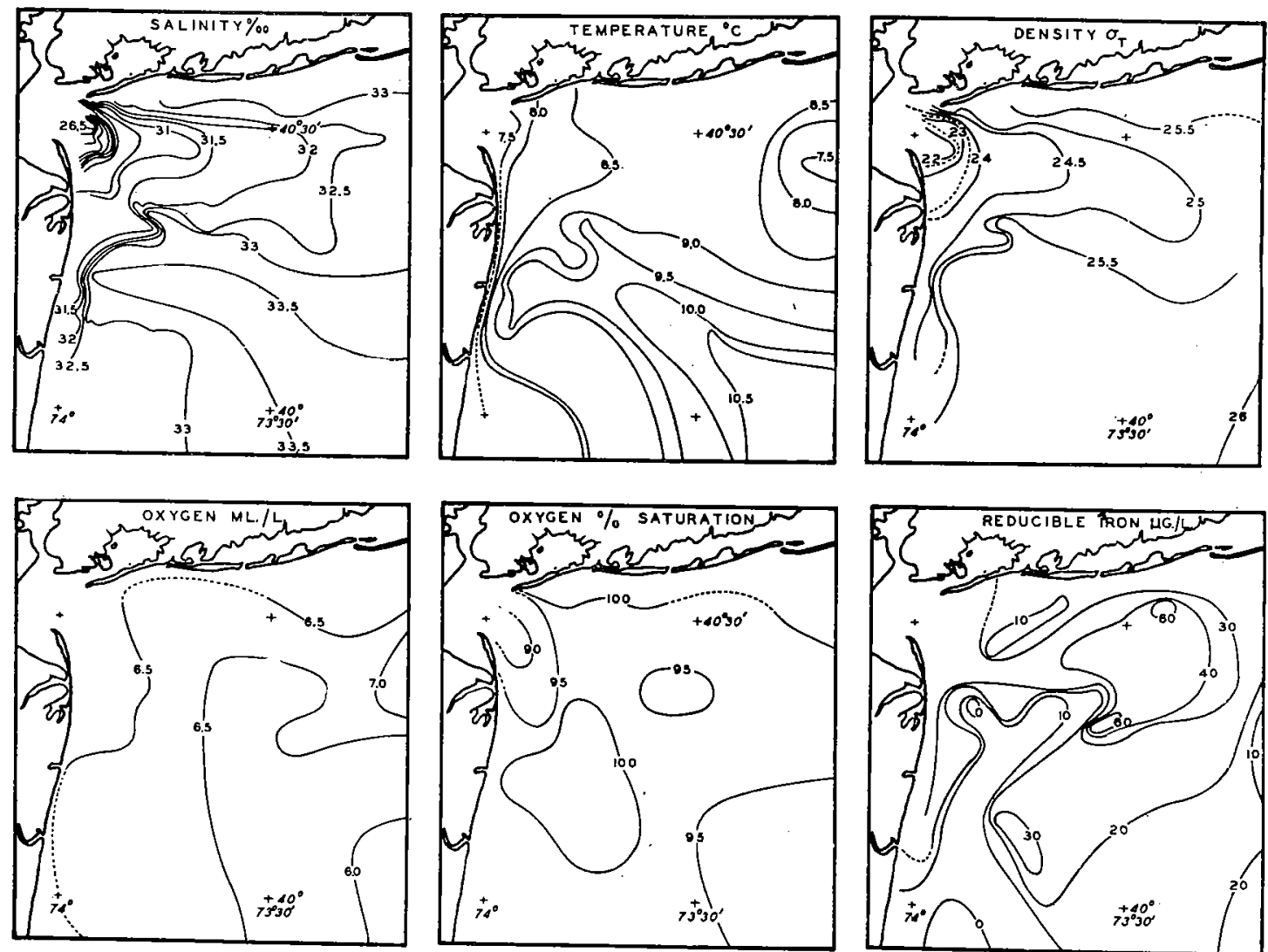

Fig. 12. Surface distribution of properties in January, 1950.

ature did not indicate continuity with subsurface water to the south, as was suggested by salinity.

The water along the New Jersey shore was supersaturated $(120 \%)$ with oxygen. The saturation values decreased seaward and most of the water more than 10 miles from the shore was less than $90 \%$ saturated.

The iron content of the water ranged from 10 to $40 \mu \mathrm{g} / 1$ over most of the surface. Over, and to the westward of the Hudson Canyon, in Sections $C$ and $D$, the iron concentrations increased towards the bottom, suggesting again the settling tendency of the particulate iron compounds.

January, 1950

The distributions observed in January, 1950, on Albatross III Cruise 30 are shown in Figures 12 and 13. The freshened river effluent at this time appears to lie partly in a band along the New Jersey shore and partly in a wider, less sharply defined band extending eastward along the Long Island shore, though separated from the coast by more saline water. There was a very pronounced gradient just outside the entrance of Lower Bay where the salinity increased from 26.5 to $30 \%$. The further increase in salinity was more gradual and extended across the entire area. In the western part of the sections there was considerable vertical gradient of salinity, particularly in Section A. To the eastward the vertical salinity gradient was negligible. 



Fig. 13. Vertical distribution of properties in January, 1950.

The river effluent was colder than the ocean water in the southeast corner of the area. In the western part of each section the temperature increased from surface to the bottom but the temperature was vertically nearly uniform to the eastward.

The oxygen concentration throughout the area was very uniform, with much of the water containing between 6.5 and $7 \mathrm{ml}$. of oxygen per liter. With the exception of a small tongue of water extending from New York Lower Bay, which was $90 \%$ saturated, the water over the entire area ranged from 95 to $100 \%$ saturated.

The iron content ranged from 0 to $60 \mu \mathrm{g} / 1$ with a patch of water of high iron content lying in the northeast part of the area. This patch lay in the vicinity where The National Lead Company was discharging acid-iron wastes. The stations within the northern part of the area were occupied from seven to twelve hours after the barge was observed discharging wastes. It will be noted that this was the only time that a localized concentration of iron was found within the area which might be attributed to these disposal operations. 


\section{EFFECT OF STORMS}

On 16 March, 1949, Balanus Cruise 19 was interrupted by a southwest storm, which destroyed the salinity pattern and produced very uniform conditions in the entire northwestern part of the area where the water appeared to be completely mixed. Subsequent surveys demonstrated the reestablishment of the circulation pattern.

The locations of the $30 \%$ isohaline after the storm, on 17, 18 and 26 March, are

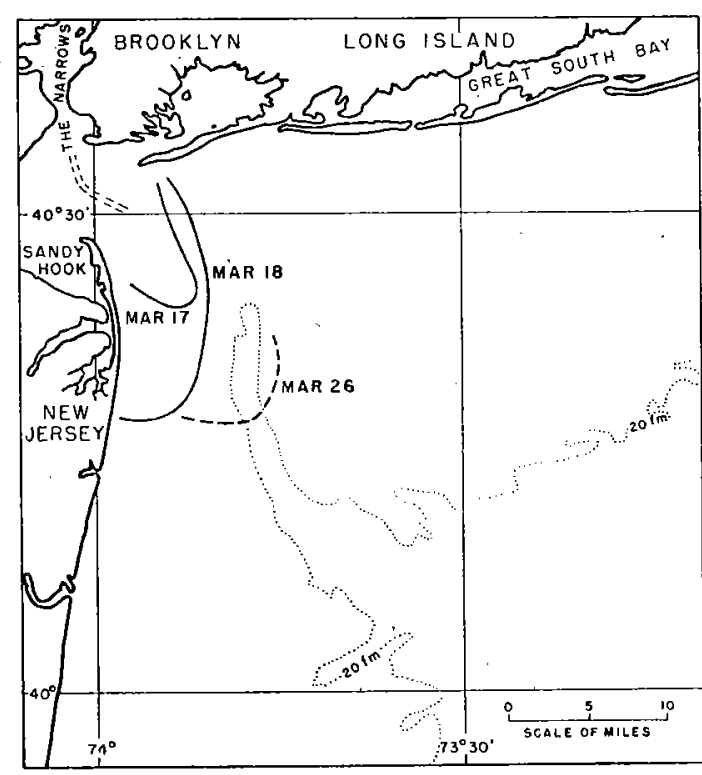

Fig. 14. Migration of the $30 \%$ isohaline on 17-26 March, 1948, following the storm of 16 March. shown in Figure 14. On the seventeenth, the day after the storm, mixed water of salinity 32.0 to $32.8 \%$ occupied all but the northwestern part of the area. Water containing enough river effluent to reduce the salinity to less than $30 \%$ was restricted to a small area in the northwest corner. After one additional day of calm weather the $30 \%$ isohaline had moved slightly to the eastward, and had extended down the New Jersey coast a distance of 7.5 miles beyond its position on the previous day. By the 26th, after eight additional days, this isohaline had not moved further southward, but had spread to the eastward, and was found about 10 miles off the New Jersey coast. These observations suggest that only about two days are required to reestablish the basic circulation patterns in the vicinity of the entrance to New York Lower Bay where the Hudson River effluent enters the area.

\section{SEASONAL VARIATIONS}

The seasonal variations in the properties of the water will be described for the stations at the western end of Section A and at the eastern end of Section D (cf. Figure 1). At the former location the river effluent dominated the water characteristics throughout the year, and at the latter station coastal water predominated, except possibly at the surface in July, 1948. At other stations, fluctuations in the proportions of river effluent present at various times produced variations which are not strictly seasonal.

The seasonal variations in the properties of the surface and bottom water at these two stations are shown in Figure 15. The river flow data which are used in interpreting the changes are given in Table IV.

At both stations maximum salinities were attained in winter when the river outflow was most closely confined to the New Jersey shore, when the river flow was moderate, and when freezing conditions in the watersheds had further reduced the runoff. The water at Scotland Light was least saline in April, during the spring freshet. The water in the southeast corner was least saline during the summer when the maximum spread of the river outflow brought freshened water closest to the station. 

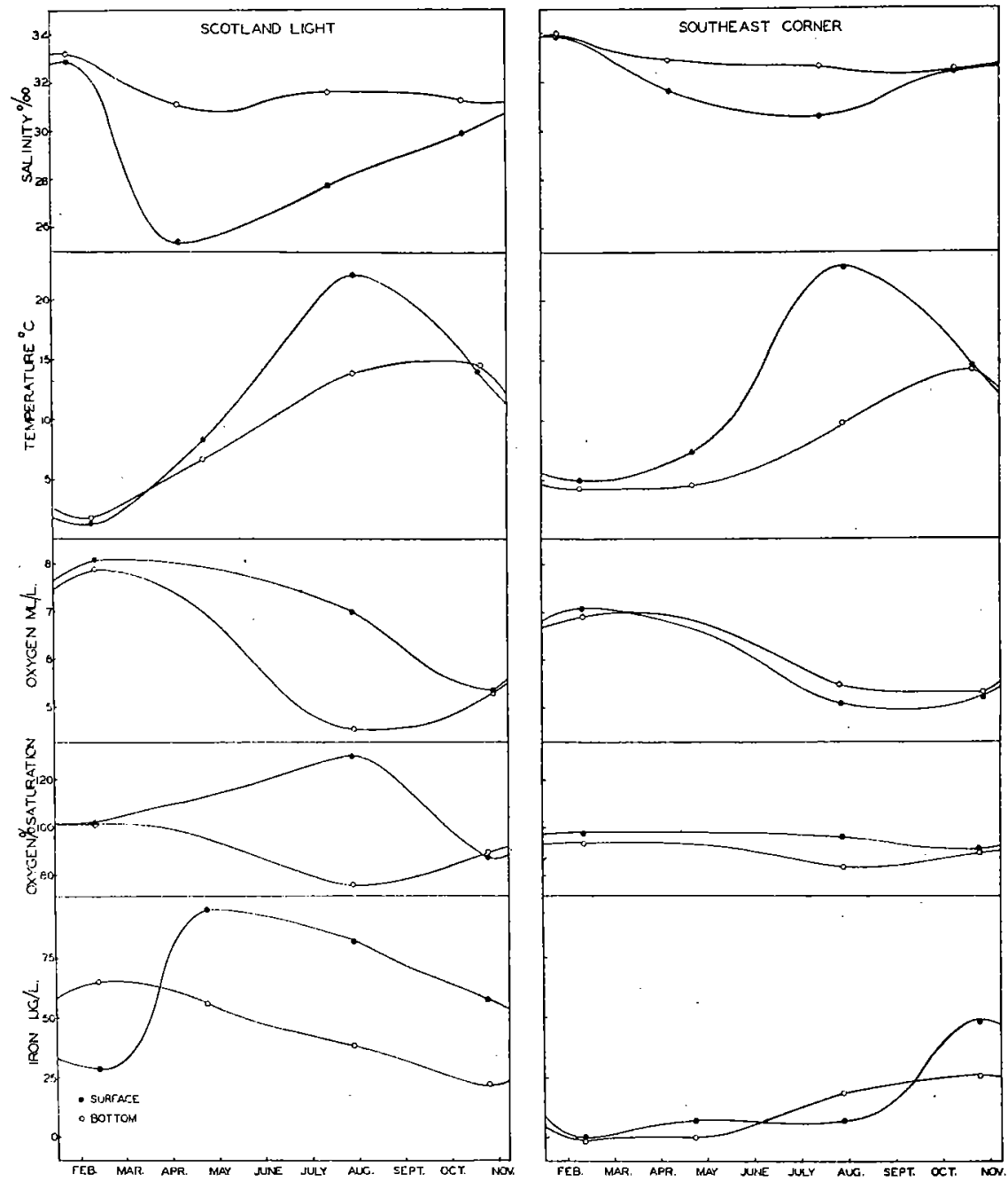

Fig. 15. Seasonal variation of properties at the station near Scotland Lightship and at the station in the southeast corner of the area. Solid circles-surface; open circles-bottom.

The fall conditions at both stations are essentially a return to the high-salinity winter conditions. The salinity of the bottom water of the southeast corner is least at this time. This may reflect the mixing action of the storm which occurred during this survey before the observations at this station were made.

The variations in the salinity of the surface water at Scotland Lightship are closely related to the runoff carried by the rivers discharging into the area. In the section of this paper discussing the rate and volume of water transport, the concentration of river water in various parts of the area have been calculated. These results are anticipated here to aid in interpreting the seasonal variations in salinity. The average proportions of fresh water in the surface water at Scotland Lightship are plotted in Figure 16 against the river flow for the appropriate time. The data show that the accumulation of river water in the inner Bight is closely related to river flow. A simple seasonal picture cannot, therefore, be expected. As was mentioned above in discussing the summer distribution patterns, the river 


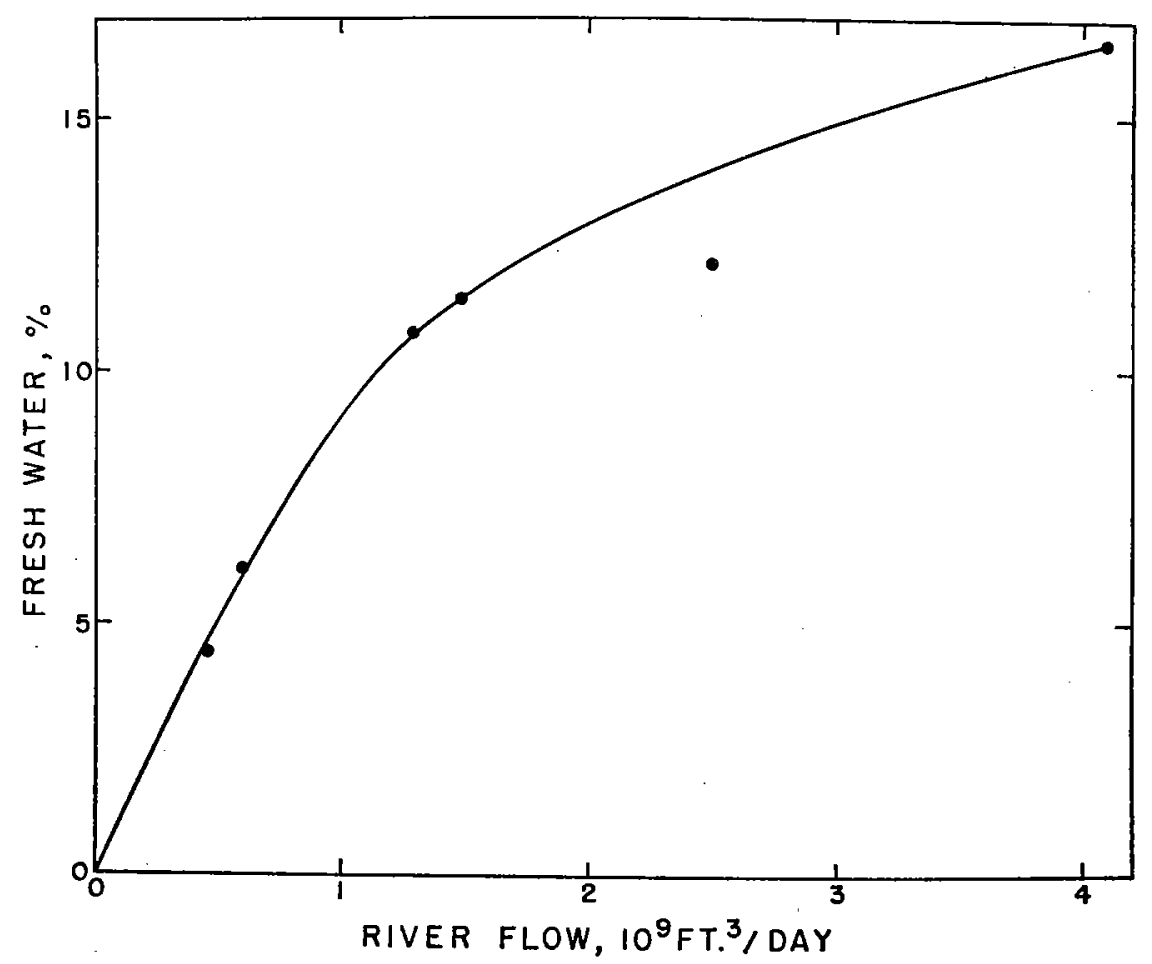

Fig. 16. The proportion of fresh water in the mixed water at the surface ( 1 meter depth) at Scotland Lightship plotted against the average river flow during the previous 30 days.

flow in July, 1948, was more than twice as great as in August, 1949. The average proportion of river water in the surveyed area was also more than twice as great in July $(0.65 \%)$ as in August $(0.21 \%)$ (cf. Table XI).

The annual temperature cycle shows that the coldest water was found at the surface at Scotland Light. The total temperature range covered during the year at Scotland Light (about $21^{\circ} \mathrm{C}$ ) was greater than at the southeasternmost station. The fact that the summer surface temperature recorded at Scotland Light was somewhat less than in the southeast is probably an effect of the tide in mixing the deeper waters with the surface. Solar heating of the surface layer of freshened water as it spreads over the area may also be important in the summer observations, since higher temperatures were found in patches immediately to the eastward of Scotland Light and in other parts of the area. The variation of temperature throughout the year showed a marked similarity at the two stations, indicating that the river effluent had much less effect on the temperature than on the other properties of the water.

The maximum oxygen concentrations were found at both stations in February, when the water was at its lowest temperature, and was 93 to $104 \%$ saturated. With the warming of the water the oxygen content decreased, reaching minimum values in the summer or fall. In July the surface water at Scotland Light was greatly supersaturated $(7.0 \mathrm{ml} / 1$; $139 \%)$. This may have been the result of photosynthetic activity. By October the waters at the two stations had oxygen contents of 5.2 to $5.5 \mathrm{ml} / 1$, and were only 85 to $92 \%$ saturated. 
The seasonal variation in iron content of the water at the southeast corner was characterized by a gradual increase and by alternation of the higher iron between surface and bottom. At Scotland Light the greater concentrations of iron were found in the surface water, except in February. The average iron content of the water at Scotland Light increased abruptly between February and April, then decreased during the rest of the year. The increase in early spring coincides in time with the maximum runoff of the rivers; it may result from the sweeping of sedimented iron from the bottoms of Lower Bay and Raritan Bay.

In the latter part of April, 1948, The National Lead Company began discharging acidiron wastes at sea over the Hudson Canyon. This iron, about 60 tons per day, was previously discharged into the Raritan River, and entered the area with the river effluents. It

is probable that the decreasing concentrations of iron in the water at Scotland Lightship reflected the removal of this amount of iron from the rivers. It is also possible that the increasing concentrations at the southeast corner are the result of these operations. The total quantity of iron within the surveyed area will be considered in a later section of this paper.

\section{DISCUSSION OF DISTRIBUTIONS}

The most striking feature of the surveys is the shift in distribution patterns between the vertically homogeneous condition, with the sea water diluted with river effluent confined to a narrow band along the New Jersey coast, and the stratified condition, with the diluted water spread widely over the area.

A seasonal change from the winter conditions of vertical homogeneity to vertical stability in summer is quite general along the continental shelf in this area (Bigelow, 1933; Bigelow and Sears, 1935; Iselin, 1936, 1940). This shift occurs even in areas which are not directly influenced by the runoff of large rivers. It appears, therefore, that these marked changes are the result of generally prevailing conditions. The rapid redevelopment of pattern after the storm in March lends credence to this conclusion. However, as mentioned above, the changes in distribution in the New York area are not strictly seasonal, and may be greatly influenced by unseasonal variations in river flow and other factors. An attempt is made in this section to determine which of the observed distributions can be assumed to be in steady state, and which may be expected to change under the existing conditions. The possible effect of the wind in maintaining anomalous distributions is discussed.

The application of the classical dynamic calculations of oceanography to coastal waters is fraught with uncertainty, since the validity of three basic assumptions is questionable. These three assumptions are, 1.) that the observed distributions are in a steady state; 2. ) that boundary friction can be neglected; and 3.) that there is a layer of no motion which may be used as a reference in computing the current. In coastal waters, change is more characteristic than the steady state, boundary conditions play an increasingly important, but unevaluated role, as one approaches shallow water and shore, and the selection of a depth of no motion is, at least, more uncertain than in the open sea. Current velocities calculated from density distributions in coastal waters, therefore, are frequently unreliable.

It is possible, however, to calculate the currents which would be required to maintain any observed set of conditions, but one cannot be assured that such currents actually exist. The estimate will be too large at times when the freshened water is tending to spread more widely, and too small when the reverse change is taking place. If independent measurements of the currents can be obtained it is possible to deduce whether the ob- 
served distributions can exist in steady state (as indicated by the agreement between the calculated and observed currents), or are in the process of change.

Between Scotland Lightship and Sandy Hook the mixture containing the river effluent is separated from denser sea water by a boundary layer in which the density gradient is large. If there were no current, this boundary layer would be horizontal with the brackish layer lying above the denser sea water. Since the boundary always slopes, at times approaching the vertical, a current must exist. The slope of the boundary layer $\frac{d z}{d x}$ is related to the densities and velocities of the two bodies of water by the following equation:

$$
\frac{\mathrm{dz}}{\mathrm{dx}}=-\frac{\mathrm{k}}{\mathrm{g}} \cdot \frac{\rho \mathrm{V}-\rho^{\prime} \mathrm{V}^{\prime}}{\rho-\rho^{\prime}}
$$

in which $\mathrm{k}$, the Coriolis force for unit mass, equals $2 \omega \sin \phi, \omega$ is the angular velocity of the earth, $\phi$ is the latitude, $g$ is the gravitational force, $\rho$ and $\rho^{\prime}$ are the densities, and $V$ and $V^{\prime}$ the velocities of the denser and less dense waters. Assuming the velocity of the denser water to be zero, and solving for the velocity of the less dense water, one obtains:

$$
\mathrm{V}^{\prime}=\frac{\mathrm{dz}}{\mathrm{dx}} \cdot \frac{\mathrm{g}}{\mathrm{k}} \cdot \frac{\rho-\rho^{\prime}}{\rho^{\prime}}
$$

From this equation the current velocity required to maintain the observed slope of the boundary layer has been calculated for each cruise and the results are given in Table II. In the final two columns of Table II are given two comparison velocities. The "observed" velocities are the average non-tidal currents obtained from direct current measurements over long periods of time by the U. S. Coast and Geodetic Survey (Marmer, 1935). The "transport" velocities are the average velocities necessary to transport the river water away from this part of the area, and are computed in the next section of this paper (Tables XIII to XVIII). These velocities represent the conditions actually existing at the time of each cruise.

The calculated velocities were substantially the same as the observed velocities at the time of the February and July, 1948, and January, 1950, cruises. At these times the observed distributions may be considered to be in steady state, and would be expected to change only after a change of conditions. In April and October, 1948, and August, 1949 , the velocities required to maintain the distributions were significantly greater than the observed velocities, indicating that these distributions might be expected to change. Since the existing current velocities were less than the calculated velocities, the slopes of the boundary layers at these times should tend to decrease, and the less dense water would be expected to spread more widely over the denser water.

In making these calculations it has been assumed that the velocity in the denser water is zero. The effect of this assumption must be assessed. If this assumption were not made, the velocities listed in Table II would be equal to:

$$
V^{\prime}-\frac{\rho}{\rho^{\prime}} V
$$


Substituting the "observed" and "transport" velocities for $V^{\prime}$, and solving for $V$ the following velocities for the denser water are obtained:

$\begin{array}{lllrl}\text { February, } & 1948 & -1.10 \text { to }-1.25 \mathrm{~cm} / \mathrm{sec} \\ \text { April, } & 1948 & -11.45 \text { to }-14.74 & " \\ \text { July, } & 1948 & +1.70 \text { to }-2.63 " \\ \text { October, } & 1948 & -13.60 \text { to }-18.66 " \\ \text { August, } & 1949 & -56.70 \text { to }-64.00 " \\ \text { January, } & 1950 & -0.60 \text { to }-1.13 "\end{array}$

The negative sign indicates that the current would flow in a direction opposite to the flow in the surface (less dense) water. Although it is necessary to have a counter drift of sea water in a net landward direction in order to maintain the distribution of salt, this counter drift must transport less volume (by one river flow per day) than the seaward trans. port of mixed water. Reference to the cross sectional distributions of salinity for these cruises (Figures $3,5,7,9,11,13$ ) shows that the denser water occupies more of the cross sectional area than does the water diluted with river effluent. The velocity of the counter drift, therefore, must be less than the velocity of the seaward drift of the diluted water. The velocities calculated for the February, July and January cruises seem reasonable on this basis of interpretation. For the other three cruises the computed velocity of the counter drift seems excessively large. Consequently, whether the velocity of the denser water is assumed to be zero or not, it is concluded that it is reasonable to assume steady state distributions for the February, July and January cruises. The distributions observed during April, October and August are not consistent with the assumption of a steady state and they may be expected to change. In each case the velocity calculated as necessary to maintain the distribution is greater than the comparison velocities, and the deduced direction of change would produce a greater spread of the water diluted with river effluent.

\section{TABLE II}

\section{Calculation of CuRRent Velocity ReQuired to Maintain} THE OBSERVEd Distribution In STEAdy STATE

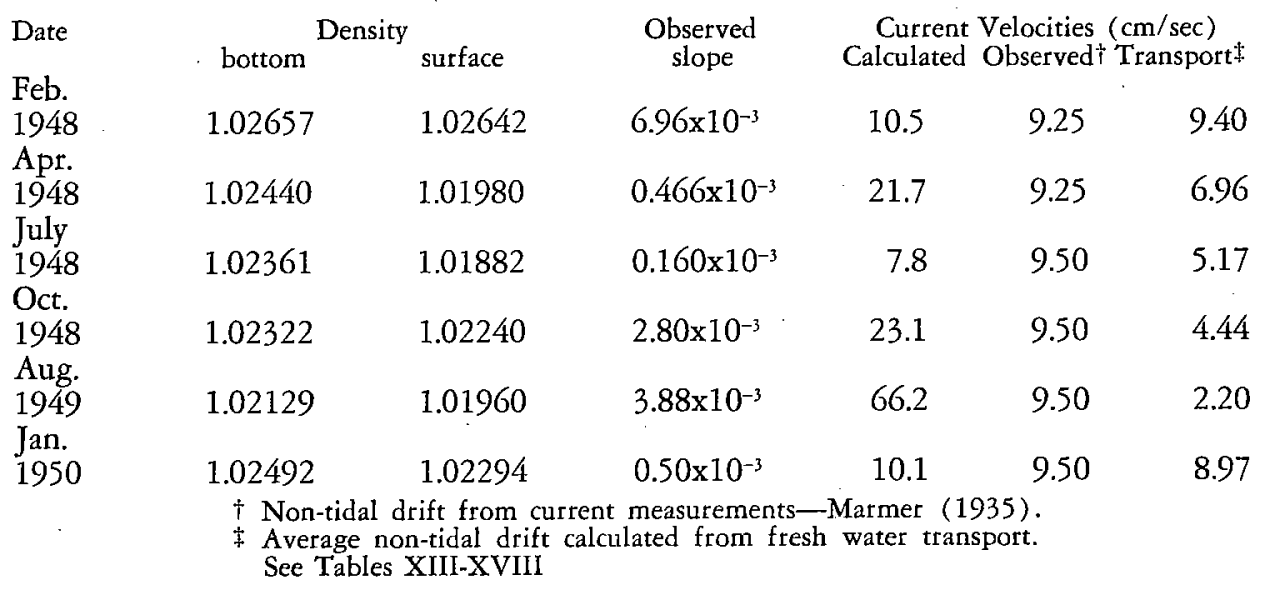


TABLE III

PREVAILING AND MAXIMUM WINDS AT NEW YORK WHEN CRUISES WERE MADE. From: U. S. Department of Commerce Monthly Weather Review, Vol. 76, 77

$\begin{array}{lccccc}\text { Cruise } & \begin{array}{c}\text { Prevailing Winds } \\ \text { Ave. hourly } \\ \text { velocity } \\ \text { mi/hr }\end{array} & \text { direction } & \begin{array}{c}\text { Maximum Winds } \\ \text { velocity } \\ \text { mi/hr }\end{array} & \text { direction } & \text { Date } \\ \text { Jan. 1948 } & 15.2 & \text { NW } & 49 & \text { NW } & 10 \\ \text { Feb. 1948 } & 14.2 & \text { N } & 48 & \text { NW } & 14 \\ \text { Apr. 1948 } & 14.9 & \text { NW } & 54 & \text { NW } & 30 \\ \text { July } 1948 & 11.5 & \text { SW } & 43 & \text { W } & 5 \\ \text { Oct. } 1948 & 13.5 & \text { N } & 39 & \text { N } & 24 \\ \text { Aug. 1949 } & 8.8 & \text { SSE } & 70 & \text { SE } & 29 \\ \text { Jan. } 1950 & 12.2 & \text { NE } & 70 & \text { W } & 14\end{array}$

In coastal waters the winds may tend to maintain anomalous distributions because of the piling up of surface waters against confining shores. It is of interest to review the wind conditions in an attempt to estimate whether they may have contributed to the maintenance of the distributions for which the assumption of a steady state appears to be untenable. The wind conditions for the appropriate periods are given in Table III.

As shown by Ekman (1902) the surface water current resulting from a wind stress is directed, in the northern hemisphere, $45^{\circ}$ to the right of the wind direction. The velocities of the deeper currents decrease rapidly, but are deflected more to the right, and the resultant net transport of water is directed $90^{\circ}$ to the right of the direction of the wind stress. In very shallow water this relationship no longer holds true, and the water current flows nearly in the direction of the surface stress at all depths. In waters of intermediate depths, such as those in the New York Bight, the deflection of the surface current is less than $45^{\circ}$ and the turning with depth is more gradual. A comprehensive theory of wind currents which would permit quantitative calculation of transport direction in shallow waters, where tidal currents are important, is not available. It is probable, however, that in such waters the net transport (in the northern hemisphere) is in a direction which lies between $45^{\circ}$ and $90^{\circ}$ to the right of the wind stress.

During the February and July cruises, when the assumption that the distributions were in steady state appeared valid, the winds would also tend to maintain the observed patterns. Thus, the February cruise was preceded by north to northwest winds which would tend to drive the brackish water southward as it emerged from the mouth of New York Lower Bay. The underlying water would move, in an Ekman spiral, to the right, i.e., against the New Jersey shore. In July, 1948, the prevailing winds were southwest and would tend to produce a net transport in an easterly direction. They would thus tend to maintain the widespread distribution of the freshened water to the eastward which was observed at this time.

During the January, 1950, cruise, the distribution also appeared to be in steady state, with a widespread band of freshened water in the northern part of the area. The winds were from the northwest, and would thus tend to hold the freshened water along the New Jersey coast. The distribution at this time, therefore, appears to be dominated by the fresh water introduced by the comparatively large river flow (cf. Table IV).

During April, 1948, when a tendency for the surface water to spread was inferred from the comparison of current velocities, the winds were from the northwest, which 
would tend to hold the freshened effluent along the shore. They opposed, therefore, the inferred tendency for the distribution pattern to change. A similar condition prevailed in October, 1948, when the northerly winds would have tended to maintain the observed distribution even though a strong tendency to change was deduced from the current comparisons. It should also be noted that the October cruise was interrupted by a northerly gale which would increase the importance of the wind effect. The calculations for August, 1949 , indicated a tendency for the less dense water to spread more widely, and the south to southeast winds at this time would tend to move the surface water in the same direction. Both the wind and the dynamic calculations indicate that this observed pattern was temporary and would be expected to change rapidly.

In a qualitative way, therefore, it appears that, with the exception of August, 1949, the wind at the time of these cruises was of a character which would tend to produce the observed anomalies. The explanation of how they are produced is more difficult. One possibility, of course, is that the wind produced an actual current greater than the average currents that we have used for comparison. If it is assumed that the velocities computed from the slopes of the boundary layers were the actual velocities of flow in the section between Scotland Lightship and the Sandy Hook shore, the volume of river water transported seaward through this section can be computed from the data in Tables XIII to XVIII. In April, the velocity required to maintain the observed slope of the boundary layer was $21.7 \mathrm{~cm} / \mathrm{sec}(61,700$ feet per day). This velocity of flow would carry seaward $71.5 \%$ of the river water contributed daily to the area. It is reasonable to assume, therefore, that at this time the current in this section was greater than the averages used for comparison in Table II. The calculated velocities for the October, 1948, and August, 1949, cruises would transport daily through this section a greater volume of river water than is provided by river flow. These velocities are, therefore, impossible, and the steady state distribution cannot exist.

In reviewing the distribution patterns, it appears in a qualitative way, that when the river flow (cf. Table IV) is fairly great the distribution patterns are well defined. Such conditions existed during the February, April, July and January cruises when the river contributions ranged from 1.3 to $4.1 \times 10^{9}$ cubic feet per day. It will be remembered that, on three of these four cruises, the current velocities necessary to maintain the distribution in steady state were comparable to observed average current velocities. The velocity required to maintain the fourth, the April, distribution in steady state was possible if most of the river water was transported southward through the Scotland Light - Sandy Hook section. The distribution patterns observed in October and August suggest erratic patterns of flow, as though the area was occupied by rather large, ill defined eddies. At both of these times the river flow was less than $0.6 \times 10^{9}$ cubic feet per day. The current velocities required to maintain these distributions were greater than the average currents used for comparison, and indeed, if they were to exist, would remove more fresh water than was provided by the river flow. It is concluded that these distributions could not exist in steady state, and the sea water diluted with river effluent could be expected to spread more widely.

The data available at present indicate that when the river flow exceeded $1.3 \times 10^{9}$ cubic feet per day, the observed distributions were what one would expect from consideration of the basic oceanographic and meteorologic factors involved, or, at least, could be explained on this basis. When the river flow was less than $0.6 \times 10^{9}$ cubic feet per day the distribution patterns were erratic, changeable, and unpredictable. 


\section{RATE AND VOLUME OF WATER TRANSPORT}

The New York Bight receives large volumes of fresh water daily from the Hudson and other rivers. Water measurably diluted with this effluent has been found throughout the surveyed area. One result of the circulation of water is the transport of this river water seaward, and the rate of this circulation can be evaluated, using the distribution of river water as a tracer. The general principles of the circulations of water in estuaries are applied to the New York Bight for this purpose.

At times of uniform river flow it can be assumed that a steady state distribution of both fresh and salt water will exist within an estuary. In order to maintain a uniform hydrostatic level and this steady state distribution, the volume of river water passing daily through each complete cross section of the estuary must equal the volume introduced daily by the river. As the river water moves seaward it mixes with progressively greater amounts of sea water. Since the river water cannot move independently, the volume of mixed water moving seaward daily must contain enough river water to maintain the balance. In order to provide the sea water in the mixture, an oceanic counter drift in a net landward direction must exist. The quantity of salt in the seaward-moving mixed water must be equal to the quantity of salt in the sea water moving landward in the same period of time, so that there is no net exchange of sea salt through the cross section. The tidal oscillations are superimposed on these non-tidal drifts, and make it difficult to observe them directly. The evaluation of the circulation of water within the New York Bight is based upon these concepts.

The proportion of river water in any sample can be calculated from the salinity, provided it can be assumed to be a mixture of river water and sea water of known salinity. The fraction of river water $(F)$ is given by:

$$
\mathrm{F}=\frac{\mathrm{S}-\mathrm{S}_{0}}{\mathrm{~S}}
$$

in which $S$ is the salinity of the source sea water and $S_{0}$ is the observed salinity of the sample. The average fraction of fresh water is designated by the symbol $F$.

The average flushing time $(T)$ for the fresh water in the estuary is given by:

$$
\mathrm{T}=\frac{F \mathrm{~V}}{\mathrm{R}}
$$

When the river flow ( $R$ ) is expressed as cubic feet per day, and the volume of water in the estuary (V) as cubic feet, this ratio gives the average flushing time in days. Tully (1949) has defined the reciprocal of this time as the displacement of fresh water per tide, expressing river flow as volume per tidal cycle. From this he has derived an expression for the proportions of water of various tidal ages present.

Through any complete cross section of an estuary, the total volume of mixed water moving seaward daily in order to transport one day's contribution of river flow is given by dividing the volume of river flow, in cubic feet per day $(R)$, by the average fraction of fresh water in the mixture, i.e., $\mathrm{R} / F$. Thus, if the average fraction of river water is onetenth, ten volumes of mixed water must move seaward in order to transport one volume of river water seaward. The volume of the oceanic counter drift is simply the difference between the volume of mixed water moving seaward and the river flow volume. In the ex- 
ample above, the oceanic counter drift provides nine volumes of water daily to mix with the river water. It is assumed in these calculations that the mixed water, i.e., the water measurably diluted with river effluent, is drifting seaward, and that the undiluted sea water is the location of the counter drift.

The average non-tidal drift (NTD) can be calculated by the equation:

$$
\mathrm{NTD}=\frac{\mathrm{R}}{F A}
$$

in which $A$ is the area of a complete cross section, extending from one side of the estuary to the other. When river flow is expressed as cubic feet per day, and area in square feet, the non-tidal drift is obtained in the units feet per day. In a river the average rate of flow is obtained simply by dividing the river flow by the cross sectional area. The calculation for the estuary differs only because the proportion of river water in the mixture (which is unity in the river) must be taken into account:

In practice, the appropriate cross sections of salinity distributions are drawn. By means of a planimeter the cross sectional areas of water of various salinities are determined. The fraction of river water in each of these areas is calculated from the salinity. This fraction, multiplied by the appropriate cross sectional area, gives the area that would be occupied by the river water if it were possible to separate it from the sea water in the mixture. The sum of these areas, then, is the fraction of the total cross sectional area occupied by the river water $(F \times A)$. From the same planimetry data the area of mixed water is also known.

\section{RIVER FLOW}

The offices of the Geological Survey at Albany, New York, and at Trenton, New Jersey, kindly supplied information on the flow of the Hudson and Raritan Rivers prior to publication. The values for the gaging station which measures the combined flow of the Hudson and Mohawk Rivers at Green Island were used for the water supply of the upper Hudson River drainage basin. This gages the flow from a drainage area of 8090 square miles of the total area of 13,366 square miles. The mean annual flow for the several streams discharging into the lower Hudson is about 1.6 cubic feet per second per square mile. Above Green Island the mean annual flow is $1.66 \mathrm{ft}^{3} / \mathrm{sec} / \mathrm{mi}^{2}$. The contribution of

\section{TABLE IV}

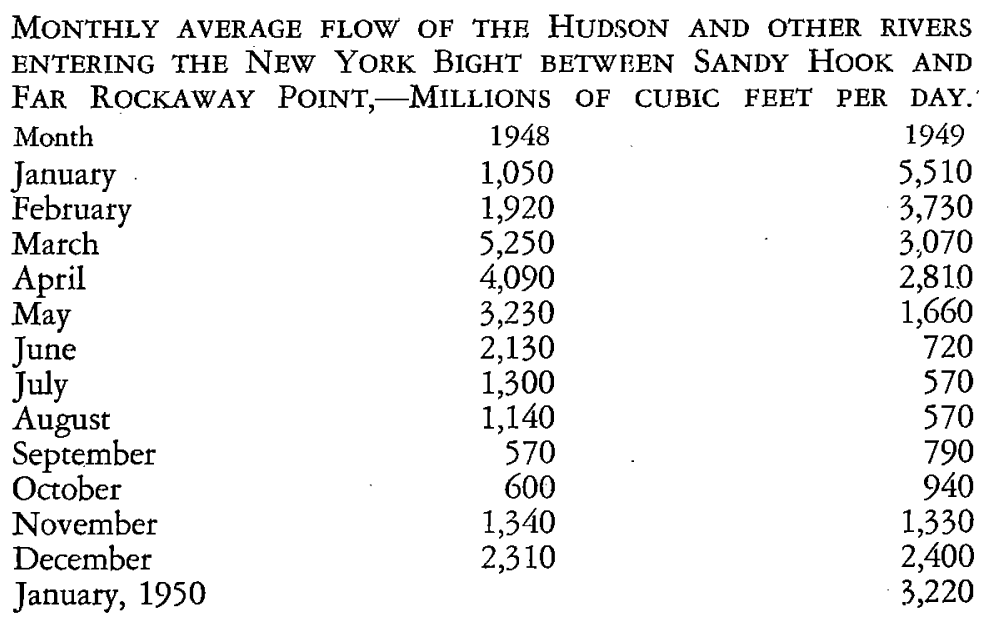


fresh water to the lower Hudson has been estimated from the relative area and these annual mean values.

The fresh water flow from the Raritan River was taken as equal to the sum of the gaging stations at Bound Brook, Farrington Dam, and Old Bridge. In 1948 the flow from the Rariton River averaged about $8.7 \%$ of the flow of the Hudson River. The sum of the mean annual flows from the Passaic, Elizabeth, Hackensack, Swimming and Rahway Rivers, and of Matawan Creek, were about $9.7 \%$ of the mean annual flow in the Hudson River. This percentage has been used to estimate the net contribution from these rivers. An example of calculation of total river flow into New York Bight (April, 1948) is given below:

$$
\begin{aligned}
& \text { Upper Hudson, Green Island gaging station } \\
& \text { Lower Hudson (Green Island x } \frac{1.6 \times 5276}{1.66 \quad 8090} \text { ) } \\
& \text { Raritan River-Bound Brook } 2114 \mathrm{ft}^{8} / \mathrm{sec} \text {. } \\
& \text { Farrington Dam } \\
& \text { Old Bridge }
\end{aligned}
$$

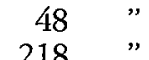

$$
\begin{aligned}
& 218 \\
& \text { Total } \\
& \text { Other Rivers ( } 9.7 \% \text { of total Hudson flow) } \\
& 25,130 \mathrm{ft}^{3} / \mathrm{sec} \text {. } \\
& 15,900 \\
& 2,380 \\
& 3,970 \quad " \\
& \text { Total average flow }=47,320 \mathrm{ft}^{8} / \mathrm{sec} \text {. } \\
& \text { Converted to flow } / \text { day }=4.09 \times 10^{\circ} \mathrm{ft}^{3} / \text { day }
\end{aligned}
$$

The monthly averages for the fresh water flow of the rivers, expressed in millions of cubic feet per day, are presented in Table IV for the years 1948 and 1949.

\section{FRESH WATER IN SURVEYED AREA}

The volume of fresh water in the area can be calculated from the salinity data, provided it can be assumed that the sample is a simple mixture of river water and of sea water of known composition.

The selection of the salinity to be assigned to the source sea water is critical. The chosen value should be characteristic of the neighboring coastal water beyond the observable direct influence of the river. An inherent assumption imposed by the calculation is that the area would be filled with water of the chosen salinity if it were not diluted with river effluent.

In the New York Bight we have used the salinity at a station about 25 miles east of Sandy Hook and 10 miles south of the Long Island shore. This was the easternmost station on Section AA or A. This water was similar to water extending eastward along the Long Island shore. Since the general coastal drift in this area is westward and southward along the shore, this water would be expected to occupy the area if the Hudson flow did not exist. The salinities for each station were averaged for ten-foot intervals using the salinity-recorder data corrected at various depths by titrated salinities. The average salinities for ten-foot depth intervals at the reference station for each cruise are shown in Figure 17.

At the surface ( 0 to $10 \mathrm{ft}$.) the salinity at the reference station varied from the July value of $30.83 \%$ o to the February value of $33.30 \%$. At the bottom the same two cruises show the extremes of $31.80 \%$ and $33.31 \%$. In January, 1950, February, 1948; and August, 1949, the water was nearly homogeneous from top to bottom. In October the 


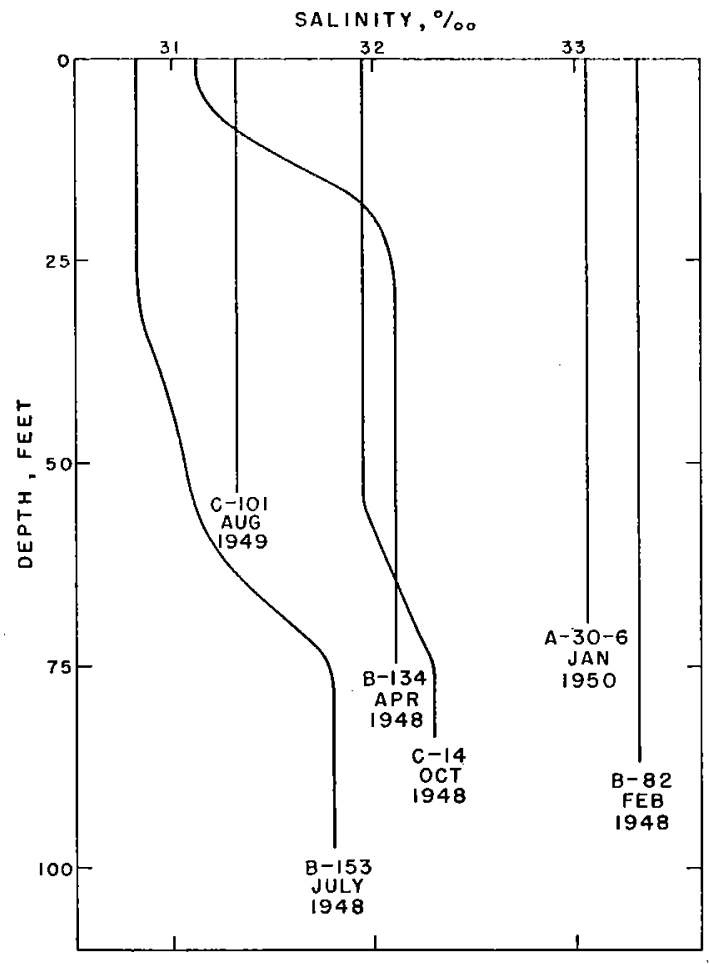

Fig. 17. The salinities averaged for depth intervals of 10 feet, at the stations selected as representative of coastal water undiluted by Hudson River drainage, for each of the cruises to the New York Bight.

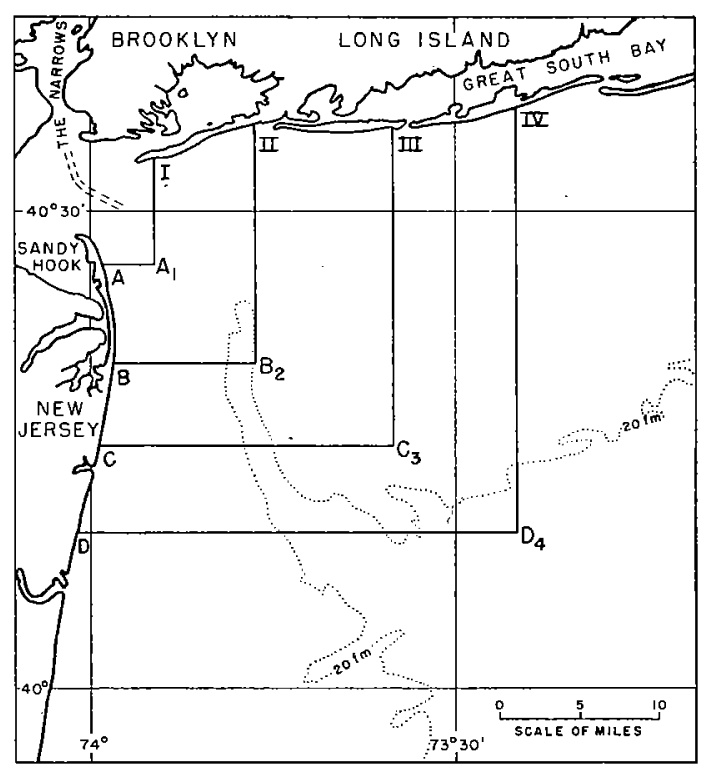

Fig. 18. Complete cross sections of the New York Bight used in evaluating water transport. mixed layer extended to 55 feet, in July to 28 feet. In April the gradient of salinity extended from the surface to 25 feet with homogeneous water from that depth to the bottom. The fresh water which dilutes the surface salinities at these times is presumably derived from land drainage along the coast to the eastward.

Comparison of the salinities of various depths at the reference station with the vertical distribution of salinity discussed above, shows the location of the river effluent. The water measurably diluted with river water is presumed to be involved in the seaward nontidal drift removing river water from the area. The water more saline than that at the reference station is presumed to be the location of the counter drift of oceanic water required to provide the sea water in the mixture.

The total volume of fresh water in various parts of the area has been determined relative to the reference stations described above. This is done by determining the area of water of various salinities in each cross section by means of a planimeter. From this the average salinity and the corresponding average percentage of fresh water in each section is determined. The total volume of each segment of the grid of stations is multiplied by the average percentage of fresh water in the surrounding sections. To identify the segments, eastwest section lines are lettered $A, B, C, D$; the north-south lines $1,2,3,4$. The segment is characterized by the station which lies in its southeast corner, i.e., the segment bounded by stations "A2-B2-B3-A3" is called segment $B_{3}$. Thus Segment $A_{1}$ is in the northwest corner, Segment $\mathrm{D}_{4}$ in the southeast corner of the grid. The total volumes of the segments and the volumes of fresh water they contain are presented in Tables $\mathrm{V}$ to $\mathrm{X}$.

On all of the cruises the maximum concentrations of river water were found along the New Jersey shore $\left(A_{1}, B_{1}, C_{1}, D_{1}\right)$. Generally, the concentrations of river water decreased to the southward in each series of segments, 
TABLE V

Distribution AND Volume of Fresh Water in the New York Survey Area in February, 1948.

Segment
$A_{1}$
$A_{2}$
$A_{3}$
$A_{4}$
$B_{1}$
$B_{2}$
$B_{3}$
$B_{4}$
$C_{1}$
$C_{2}$
$C_{3}$
$C_{4}$
$D_{1}$
$D_{2}$
$D_{3} \& D_{4}$
$T_{4}$

Surface

Area
$10^{3} \mathrm{ft}^{3}$

0.32

1.57

1.39

1.42

0.58

1.43

.1 .25

1.14

0.51

1.15

0.93

0.94

0.73

1.81

2.72

17.89

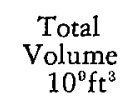

7.6

84

78

78

20

117

111

86

22

101

96

74

36

159

329

1399

\section{Freshened
Volume \\ Volume
$10^{\circ} \mathrm{ft}^{3}$}

7.6

84

78

78

20

107

106

86

22

83

77

63

- 36

145

126

1119

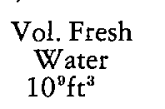

0.19

0.58

0.57

0.56

1.15

0.84

0.65

0.49

0.67

0.56

0.33

0.23

0.89

0.89

0.32

8.92

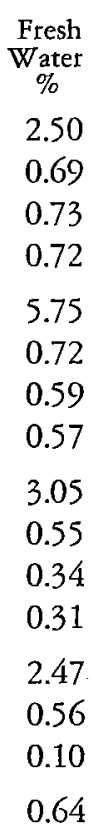

TABLE VI

Distribution AND VOLUME OF FRESH WATER IN THe New York Survey Area IN APril, 1948.

Segment
$A_{1}$
$A_{2}$
$A_{3}$
$A_{1}$
$B_{1}$
$B_{2}$
$B_{3}$
$B_{4}$
$C_{1}$
$C_{2}$
$C_{3}$
$C_{4}$
$D_{1}$
$D_{2}$
$D_{3}$
$D_{4}$

Surface
Area

$10^{8} \mathrm{ft}^{2}$

0.22

1.64

2.25

2.30

0.46

1.43

1.59

1.47

Total

Volume
$10^{\circ} \mathrm{ft}^{3}$

4.6

96

146

148

14

111

128

120

0.50

1.38

1.82

1.72

0.82

1.54

2.03

3.32

24.49

24

122

158

158

48

140

229

340

1987

\begin{tabular}{|c|}
\hline $\begin{array}{l}\text { Freshened } \\
\text { Volume } \\
10^{\mathrm{a}} \mathrm{ft}^{\mathrm{z}}\end{array}$ \\
\hline 4.6 \\
\hline 84 \\
\hline 127 \\
\hline 134 \\
\hline 14 \\
\hline 86 \\
\hline 95 \\
\hline 88 \\
\hline 24 \\
\hline 83 \\
\hline 82 \\
\hline 52 \\
\hline 46 \\
\hline 93 \\
\hline 98 \\
\hline 84 \\
\hline
\end{tabular}

1195

$\begin{array}{cr}\begin{array}{c}\text { Vol. Fresh } \\ \text { Water } \\ 10^{\circ} \mathrm{ft}^{8}\end{array} & \begin{array}{c}\text { Fresh } \\ \text { Water } \\ \%\end{array} \\ 0.55 & 11.95 \\ 4.97 & 5.18 \\ 2.49 & 1.71 \\ 0.78 & 0.53 \\ 1.40 & 10.00 \\ 3.90 & 3.51 \\ 1.92 & 1.50 \\ 0.69 & 0.58 \\ 1.12 & 4.67 \\ 2.70 & 2.21 \\ 2.07 & 1.31 \\ 0.57 & 0.36 \\ 1.64 & 3.42 \\ 2.56 & 1.83 \\ 2.04 & 0.89 \\ 1.01 & 0.30 \\ 30.41 & 1.53\end{array}$


TABle VII

Distribution AND Volume OF FRESH WATER IN THE NEW YORK SURvey AREA IN JULY, 1948.

\begin{tabular}{|c|c|c|c|c|c|}
\hline Segment & $\begin{array}{c}\text { Surface } \\
\text { Area } \\
10^{\circ} \mathrm{ft}^{2}\end{array}$ & $\begin{array}{c}\text { Total } \\
\text { Volume } \\
10^{8} \mathrm{ft}^{3}\end{array}$ & $\begin{array}{l}\text { Freshened } \\
\text { Volume } \\
10^{\mathrm{a}} \mathrm{ft}^{3}\end{array}$ & $\begin{array}{c}\text { Vol. Fresh } \\
\text { Water } \\
10^{9} \mathrm{ft}^{3}\end{array}$ & $\begin{array}{l}\text { Fresh } \\
\text { Water } \\
\%\end{array}$ \\
\hline$A_{1}$ & 0.33 & 7.1 & 7.1 & 0.37 & 5.21 \\
\hline$A_{2}$ & 2.01 & 102 & 56 & 2.62 & 2.57 \\
\hline$A_{3}$ & 2.76 & 161 & 77 & 2.37 & 1.47 \\
\hline $\mathrm{A}_{4}^{\circ}$ & 3.22 & 180 & 87 & 0.85 & 0.47 \\
\hline $\mathrm{B}_{1}$ & 0.54 & 17 & 14 & 0.47 & 2.76 \\
\hline $\mathrm{B}_{2}$ & 1.54 & 131 & 43 & 1.11 & 0.85 \\
\hline $\mathrm{B}_{3}$ & 1.89 & 153 & 57 & 1.15 & 0.75 \\
\hline $\mathrm{B}_{4}$ & 2.11 & 177 & 42 & 0.34 & 0.19 \\
\hline$C_{1}$ & 0.47 & 20 & 20 & 0.23 & 1.15 \\
\hline $\mathrm{C}_{2}$ & 1.26 & 115 & 33 & 0.44 & 0.38 \\
\hline $\mathrm{C}_{3}^{2}$ & 1.55 & 145 & 49 & 0.54 & 0.37 \\
\hline $\mathrm{C}_{4}$ & 1.59 & 131. & 37 & 0.24 & 0.18 \\
\hline $\mathrm{D}_{1}$ & 0.80 & 40 & 16 & 0.26 & 0.65 \\
\hline $\mathrm{D}_{2}$ & 1.53 & 139 & 38 & 0.79 & 0.57 \\
\hline $\mathrm{D}_{3}$ & 1.88 & 229 & 51 & 0.69 & 0.30 \\
\hline $\mathrm{D}_{4}$ & 1.78 & 198 & 35 & 0.19 & 0.10 \\
\hline Total & 25.26 & 1945 & 662 & 12.66 & 0.65 \\
\hline
\end{tabular}

TABLE VIII

Distribution AND Volume OF FRESH WATER IN THE New YORK SURvey AREA IN OCTOBER, 1948.

Segment

$A_{1}$

$\mathrm{A}_{2}$

$\mathrm{A}_{3}$

$\mathrm{A}_{4}$

$\mathrm{B}_{1}$

$\mathrm{B}_{2}$

$\mathrm{B}_{3}$

$\mathrm{B}_{4}$

$\mathrm{C}_{1}$

$\mathrm{C}_{2}$

$\mathrm{C}_{3}$

$\mathrm{C}_{4}$

Total

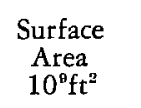

0.68

1.55

2.44

2.54

0.52

1.51

1.84

1.77

- 0.47

1.27

1.55

1.47

17.61

Total
Volume
$10^{\circ} \mathrm{ft}^{5}$
12.6
92
152
153
16
129
151
143
18
117
141
135
1260

1260

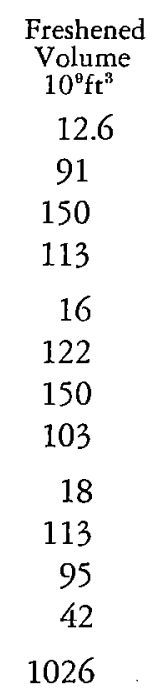

$\begin{array}{cc}\begin{array}{c}\text { Vol. Fresh } \\ \text { Water } \\ 10^{\mathrm{f}} \mathrm{ft}^{3}\end{array} & \begin{array}{c}\text { Fresh } \\ \text { Water } \\ \% \\ 0.22\end{array} \\ 0.96 & 1.75 \\ 0.73 & 1.04 \\ 0.17 & 0.48 \\ 0.64 & 0.11 \\ 1.22 & 4.00 \\ 0.50 & 0.95 \\ 0.41 & 0.33 \\ 0.39 & 0.29 \\ 0.47 & 2.17 \\ 0.43 & 0.40 \\ 0.20 & 0.30 \\ 6.34 & 0.15 \\ & 0.50\end{array}$


TABLE IX

Distribution and Volume OF Fresh WATER IN THe New York Survey Area IN August, 1949.

\begin{tabular}{|c|c|c|c|c|c|}
\hline Segment & $\begin{array}{c}\text { Surface } \\
\text { Area } \\
10^{\circ} \mathrm{ft}^{2}\end{array}$ & $\begin{array}{l}\text { Total } \\
\text { Volume } \\
10^{0} \mathrm{ft}^{3}\end{array}$ & $\begin{array}{c}\text { Freshened } \\
\text { Volume } \\
10^{\circ} \mathrm{ft}^{3}\end{array}$ & $\begin{array}{c}\text { Vol. Fresh } \\
\text { Water } \\
10^{0} \mathrm{ft}^{3}\end{array}$ & $\begin{array}{c}\text { Fresh } \\
\text { Water } \\
\%\end{array}$ \\
\hline$A_{1}$ & 0.38 & 8.8 & 8.3 & 0.32 & 3.64 \\
\hline$A_{2}$ & 2.22 & 133 & 46 & 0.93 & 0.70 \\
\hline$A_{3}$ & 2.90 & 176 & 16 & 0.06 & 0.03 \\
\hline$A_{4}$ & 2.71 & 170 & 41 & 0.09 & 0.05 \\
\hline$B_{1}$ & 0.50 & 18 & 16 & 0.61 & 3.39 \\
\hline $\mathrm{B}_{2}$ & 1.21 & 112 & 18 & 0.03 & 0.03 \\
\hline $\mathrm{B}_{3}$ & 1.47 & 124 & 0 & 0 & 0 \\
\hline$B_{4}$ & 1.77 & 153 & 0 & 0 & 0 \\
\hline$C_{1}$ & 0.47 & 36 & 18 & 0.37 & 1.03 \\
\hline $\mathrm{C}_{2}$ & 1.41 & 183 & 43 & 0.47 & 0.26 \\
\hline $\mathrm{C}_{3}$ & 1.75 & 92 & 0 & 0 & 0 \\
\hline$C_{4}$ & 1.63 & 95 & 2 & 0.01 & 0.01 \\
\hline $\mathrm{D}_{1}$ & 0.27 & 38 & 11 & 0.25 & 0.66 \\
\hline $\mathrm{D}_{2}$ & 2.23 & 183 & 55 & 0.47 & 0.26 \\
\hline $\mathrm{D}_{3}$ & 0.96 & 113 & 3 & 0.01 & 0.01 \\
\hline $\mathrm{D}_{4}$ & 1.37 & 115 & 1 & 0.01 & 0.01 \\
\hline Total & 23.25 & 1750 & 278 & 3.63 & 0.21 \\
\hline
\end{tabular}

TABLE X

Distribution AND Volume OF Fresh WATER in the New York Survey ARea IN JANUARY, 1950.

$\begin{array}{lccccc}\text { Segment } & \begin{array}{c}\text { Surface } \\ \text { Area } \\ 10^{\circ} \mathrm{ft}^{2}\end{array} & \begin{array}{c}\text { Total } \\ \text { Volume } \\ 10^{0} \mathrm{ft}^{3}\end{array} & \begin{array}{c}\text { Freshened } \\ \text { Volume } \\ 10^{0} \mathrm{ft}^{3}\end{array} & \begin{array}{c}\text { Vol. Fresh } \\ \text { W ater } \\ 10^{\circ} \mathrm{ft}^{3}\end{array} & \begin{array}{c}\text { Fresh } \\ \text { Water } \\ \%\end{array} \\ \mathrm{~A}_{1} & 0.32 & 6.9 & 6.9 & 0.61 & 8.84 \\ \mathrm{~A}_{2} & 1.35 & 63 & 45 & 1.69 & 2.68 \\ \mathrm{~A}_{3} & 3.15 & 153 & 118 & 1.67 & 1.09 \\ \mathrm{~A}_{4} & 2.93 & 139 & 78 & 1.32 & 0.95 \\ \mathrm{~B}_{1} & 0.56 & 22 & 19 & 1.47 & 6.68 \\ \mathrm{~B}_{2} & 0.98 & 78 & 32 & 1.34 & 1.72 \\ \mathrm{~B}_{3} & 1.54 & 133 & 49 & 1.28 & 0.96 \\ \mathrm{~B}_{4} & 1.65 & 136 & 102 & 1.96 & 1.44 \\ \mathrm{C}_{1} & 0.93 & 53 & 31 & 1.30 & 2.45 \\ \mathrm{C}_{2} & 0.59 & 74 & 9 & 0.18 & 0.24 \\ \mathrm{C}_{3} & 1.54 & 152 & 28 & 0.58 & 0.38 \\ \mathrm{C}_{4} & 0.89 & 80 & 51 & 0.65 & 0.81 \\ \mathrm{D}_{1} & 1.46 & 105 & 34 & 1.25 & 1.19 \\ \mathrm{D}_{2} & 1.26 & 119 & 5 & 0.03 & 0.03 \\ \mathrm{D}_{3} & 2.70 & 338 & 5 & 0.03 & 0.01 \\ \mathrm{D}_{4} & 2.19 & 243 & 57 & 0.33 & 0.14 \\ \text { Total } & 24.04 & 1895 & 670 & 15.69 & 0.83\end{array}$




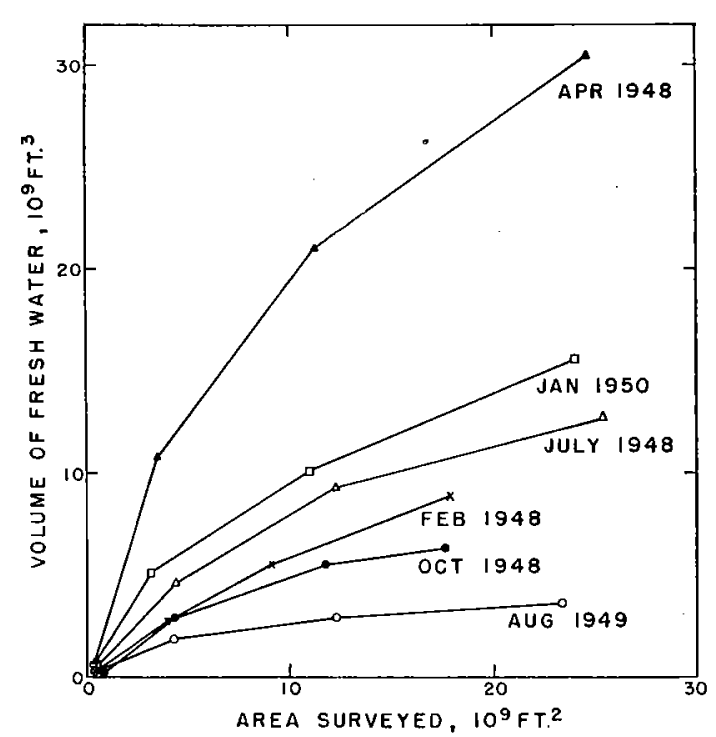

Fig. 19. The volumes of river water accumulated within the areas enclosed by the cross sections shown in Figure 18.

though the water lying between Section A and $\mathrm{B}$ occasionally contained more river water than the adjacent segment to the north. The decrease of the concentration of river water in an easterly direction was rapid in February and October, 1948, and in August, 1949. This decrease was more gradual in April and June, 1948 , and in January, 1950, particularly in the northern part of the area.

The freshened volume in these tables is the volume of water within each segment less saline than the water at comparable depths at the reference station. In all of the volume segments along the New Jersey shore practially all of the water was mixed with the river effluent. To the east and to the south the proportion of the water so diluted decreased, and the smallest proportion of mixed water was generally found in the southeastern part of the area. In the entire area the proportion of water measurably freshened ranged from about $16 \%$ in August, 1949, to $80 \%$ in February and October, 1948. In August the river flow was very low, and large volumes of water in the eastern part of the area contained no measurable river water. Curiously, the river flow in October was also low, but at this time the river water was detectable throughout most of the area. As was mentioned above, the October cruise was interrupted by a storm, and the extensive mixing observed may have been a direct result.

In Table XI, the results for the entire surveyed area are summarized. The average river flow during the 30 days preceding each cruise is included to permit comparison between the observed conditions and river flow ${ }^{\mathrm{a}}$. It is apparent, for example, that the concentration of river water increased with increasing river flow. This relationship has been used to aid in interpreting seasonal variations of salinity (cf. Figure 16).

The average time required for a unit volume of river water to escape from the area is given as the average flushing time in the bottom line of Table XI. In spite of almost ninefold variations in river flow the average flushing time varied only from 6 to 10.6 days.

This comparison is not precise, since the surveyed area varied from 483 to 683 square miles, and the larger area would naturally contain a greater volume of river water. In order to permit direct comparisons, the cumulativevolumes within the consecutive areas bounded by right-angled cross sections, shown in Figure 18, have been computed, and the results are presented in Table XII and in Figure 19. For any given surface area the amount of river water accumulated increased with increasing river flow. There is one exception to this generalization, namely the February, 1948, cruise, when the contained river water was less than in July, 1948, though the river flow was greater. The lower Hudson River was solidly

a This omits the direct contribution of fresh water by rain on the area, and all loss by evaporation. The size of the surveyed area is only $3-4 \%$ of the area of the drainage basins, and the direct contribution of rain would be cortespondingly small. 


\section{TABLE XI}

\begin{tabular}{|c|c|c|c|c|c|c|}
\hline \multicolumn{7}{|c|}{$\begin{array}{l}\text { SUMMARY OF VOLUME OF FreSH WATER } \\
\text { IN THE NEW YORK SURVEY AREA. }\end{array}$} \\
\hline $\begin{array}{c}\text { Cruise No. } \\
\text { Time }\end{array}$ & $\begin{array}{l}\text { B-18 } \\
\text { Feb. ' } 48\end{array}$ & $\begin{array}{l}\text { B-20 } \\
\text { Apr. } 448\end{array}$ & $\begin{array}{l}\text { B-22 } \\
\text { July ' } 48\end{array}$ & $\begin{array}{c}\text { C- }-4^{\circ} \\
\text { Oct. } 48\end{array}$ & $\begin{array}{c}\text { C-12 } \\
\text { Aug. } 49\end{array}$ & $\begin{array}{r}\text { AllI-30 } \\
\text { Jan. '50 }\end{array}$ \\
\hline Area Surveyed & & & & & & \\
\hline $\begin{array}{c}\text { sq. miles } \\
\text { Total Volume }\end{array}$ & 483 & 662 & 683 & 476 & 628 & 650 \\
\hline $\begin{array}{l}10^{8} \mathrm{ft}^{3} \\
\text { Vol. Freshened }\end{array}$ & 1399 & 1987 & 1945 & 1260 & 1750 & 1895 \\
\hline & 1119 & 1195 & 662 & 1026 & 278 & 670 \\
\hline $\begin{array}{c}10^{\circ} \mathrm{ft}^{3} \\
\text { River Water }\end{array}$ & 8.92 & 30.41 & 12.66 & 6.34 & 3.63 & 15.69 \\
\hline$\%$ of Total Volume & 0.64 & 1.53 & 0.65 & 0.50 & 0.21 & 0.83 \\
\hline$\%$ of "Freshened" & 0.80 & 2.54 & 1.91 & 0.62 & 1.31 & 2.34 \\
\hline $\begin{array}{l}\text { River Flow } \\
10^{\circ} \mathrm{ft}^{3} / \text { day } \\
\text { Average Flushing }\end{array}$ & 1.49 & 4.09 & 1.30 & 0.60 & 0.46 & 2.51 \\
\hline Time-days & 6.0 & 7.4 & 9.7 & 10.6 & 7.9 & 6.3 \\
\hline
\end{tabular}

\section{TABLE XII}

Volumes OF RIVER WATER IN THE CONSECutive AREAS SHOWN IN Figure 18.

\begin{tabular}{|c|c|c|c|}
\hline Date & $\begin{array}{l}\text { Enclosing } \\
\text { Section }\end{array}$ & $\begin{array}{c}\text { Surface } \\
\text { Area } \\
10^{8} \mathrm{ft}^{2}\end{array}$ & $\begin{array}{c}\text { Volume } \\
\text { Fresh Water } \\
10^{\theta} \mathrm{ft}^{3}\end{array}$ \\
\hline Feb., 1948 & $\begin{array}{lll}A & A_{1} & \text { I } \\
\text { B } & B_{2} & \text { II } \\
C & C_{3} & \text { III } \\
D^{2} & D_{4} & \text { IV }\end{array}$ & $\begin{array}{r}0.32 \\
3.90 \\
9.13 \\
17.89\end{array}$ & $\begin{array}{l}0.19 \\
2.76 \\
5.54 \\
8.92\end{array}$ \\
\hline Apr., 1948 & $\begin{array}{lll}A & A_{1} & \text { I } \\
\text { B } & B_{2} & \text { II } \\
C & C_{3} & \text { III } \\
\text { D } & D_{4} & \text { IV }\end{array}$ & $\begin{array}{r}0.22 \\
3.75 \\
11.29 \\
24.49\end{array}$ & $\begin{array}{r}0.55 \\
10.82 \\
21.12 \\
30.41\end{array}$ \\
\hline July, 1948 & $\begin{array}{lll}A & A_{1} & \text { I } \\
\text { B } & B_{2} & \text { II } \\
C & C_{3} & \text { III } \\
\text { D } & D_{1} & \text { IV }\end{array}$ & $\begin{array}{r}0.33 \\
4.42 \\
12.35 \\
25.26\end{array}$ & $\begin{array}{r}0.37 \\
4.57 \\
9.30 \\
12.66\end{array}$ \\
\hline Oct., 1948 & $\begin{array}{lll}A & A_{1} & \text { I } \\
B & B_{2} & \text { II } \\
C & C_{3} & \text { III } \\
C & C_{4} & \text { IV }\end{array}$ & $\begin{array}{r}0.68 \\
4.26 \\
11.83 \\
17.61\end{array}$ & $\begin{array}{l}0.22 \\
3.04 \\
5.56 \\
6.34\end{array}$ \\
\hline Aug., 1949 & $\begin{array}{lll}\mathrm{A} & \mathrm{A}_{1} & \mathrm{I} \\
\mathrm{B} & \mathrm{B}_{2} & \mathrm{II} \\
\mathrm{C} & \mathrm{C}_{3} & \mathrm{III} \\
\mathrm{D} & \mathrm{D}_{4} & \mathrm{IV}\end{array}$ & $\begin{array}{r}0.38 \\
4.31 \\
12.31 \\
23.25\end{array}$ & $\begin{array}{l}0.32 \\
1.89 \\
2.79 \\
3.63\end{array}$ \\
\hline Jan., 1950 & $\begin{array}{lll}A & A_{1} & \text { I } \\
B & B_{2} & \text { II } \\
C & C_{3} & \text { III } \\
\text { D } & D_{2} & \text { IV }\end{array}$ & $\begin{array}{r}0.32 \\
3.21 \\
10.96 \\
24.04\end{array}$ & $\begin{array}{r}0.61 \\
5.11 \\
10.12 \\
15.69\end{array}$ \\
\hline
\end{tabular}




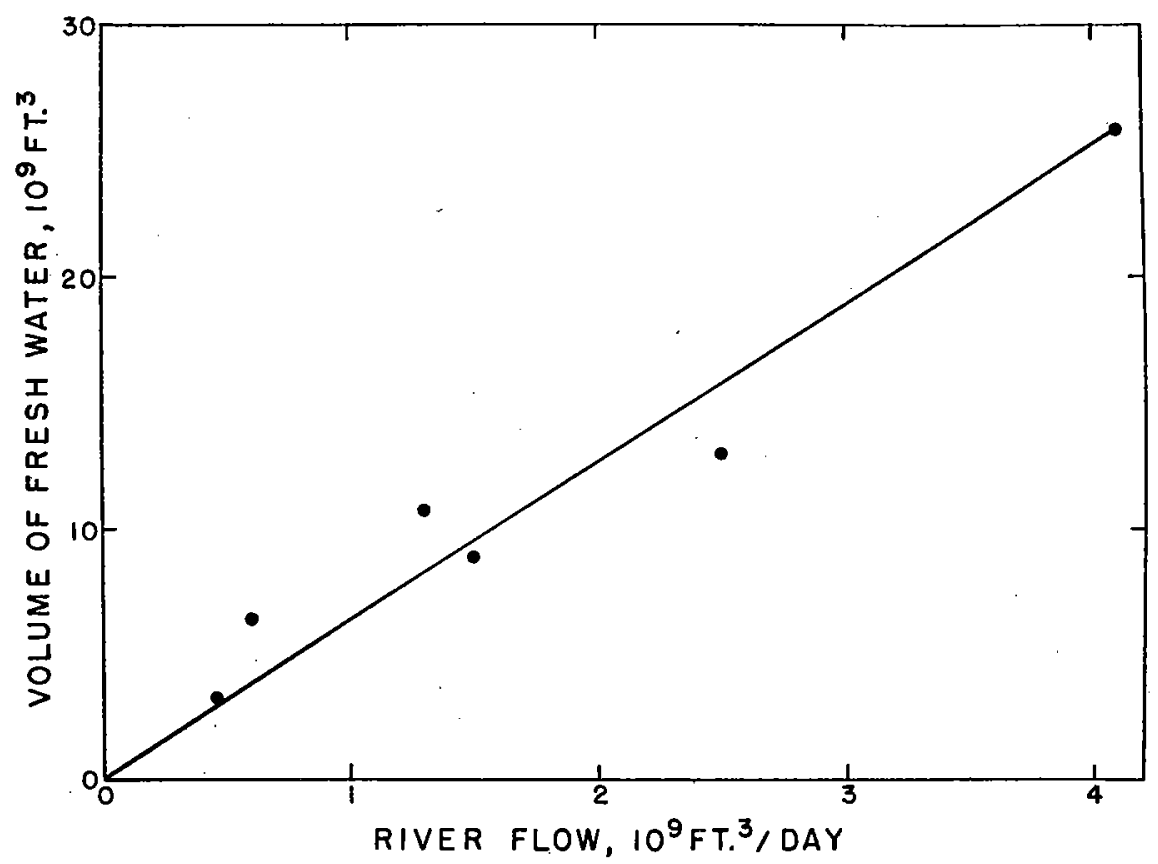

Fig. 20. The volume of river water in an area of approximately 500 square miles of the New York Bight related to the river flow during the preceding 30 days.

frozen over in February, 1948, and it is quite possible that the gaged river flow gave too high a value for the actual flow into the sea.

From Figure 19 the volume of river water within any chosen area can be read from the various curves. The volumes within $17.6 \times 10^{9} \mathrm{ft}^{2}$ (approximately 500 square miles) are compared to river flow in Figure 20. The line drawn in this figure corresponds to a flushing time of 6.3 days. Since the results of the various cruises correspond with this time, within the accuracy of the survey methods, it can be concluded that the rate of flushing of this area is independent of the daily volume of river flow. Increased river flow thus increases the concentration of river water within the area, but does not control the average rate of movement through the area.

\section{NON-TIDAL DRIFTS}

The distribution of river water in various cross sections has been used to compute the velocity of the net seaward drift of the mixed water, and to evaluate the volume of sea water involved in the circulation. The volume of sea water entrained in the seaward nontidal drift of mixed water is indirectly a measure of the volume of the oceanic counter drift, since, in order to maintain the steady state distribution, there must be no net exchange of salt across the section. In making the calculations it is assumed that all of the mixed water is moving seaward. Where the entire cross sectional area contains mixed water, the velocity of the seaward drift will actually be greater than that calculated, since the more saline water in the cross section must be the location of the counter drift of sea water. This condition is found only in the innermost sections. The exchanges across the four right-angled sections in Figure 18 have been evaluated. The results are presented in Tables XIII to XVIII. 


\section{TABLE XIII}

Fresh Water Transport Through Various Sections off New York, FEBRUARY, 1948. RIVER FLOW $=1.49 \times 10^{\circ} \mathrm{ft}^{3} /$ day.

\begin{tabular}{|c|c|c|c|c|c|c|c|c|}
\hline Section & $\begin{array}{l}\text { Area of } \\
\text { Section } \\
10^{4} \mathrm{ft}^{2}\end{array}$ & $\begin{array}{c}\text { Freshened } \\
\text { Area } \\
10^{4} \mathrm{ft}^{2}\end{array}$ & $\begin{array}{l}\text { Fresh } \\
\text { Water } \\
\%\end{array}$ & $\begin{array}{l}\text { Area } \\
\text { Fresh } \\
1^{4} \mathrm{ft}^{2}\end{array}$ & $\begin{array}{c}\text { Net } \\
\text { Drift } \\
\text { ft } / \text { day }\end{array}$ & $\begin{array}{l}\text { Tran } \\
10^{\circ} \mathrm{ft} \\
\text { Fresh }\end{array}$ & $\begin{array}{l}\text { ort } \\
\text { day } \\
\text { Total }\end{array}$ & $\begin{array}{c}\text { Relative } \\
\text { Volumes } \\
\text { Total/fresh }\end{array}$ \\
\hline $\begin{array}{l}A-A_{1} \\
A_{1-1}\end{array}$ & $\begin{array}{r}58 \\
163\end{array}$ & $\begin{array}{r}58 \\
163\end{array}$ & $\begin{array}{l}7.93 \\
0.60\end{array}$ & $\begin{array}{l}4.60 \\
0.98\end{array}$ & $\begin{array}{l}26,300 \mathrm{a} \\
28,600\end{array}$ & $\begin{array}{l}1.21 \\
0.28\end{array}$ & $\begin{array}{l}15 \\
47\end{array}$ & \\
\hline Total & 221 & 221 & 2.52 & 5.58 & & 1.49 & 62 & 42 \\
\hline $\begin{array}{l}\mathrm{B}-\mathrm{B}_{2} \\
\mathrm{~B}_{2}-2\end{array}$ & $\begin{array}{l}346 \\
761 \\
\end{array}$ & $\begin{array}{l}298 \\
632\end{array}$ & $\begin{array}{l}1.02 \\
0.67\end{array}$ & $\begin{array}{l}3.04 \\
4.22\end{array}$ & & $\begin{array}{l}0.625 \\
0.865\end{array}$ & $\begin{array}{r}61 \\
130\end{array}$ & \\
\hline Total & 1107 & 930 & 0.78 & 7.26 & 20,500 & 1.49 & 191 & 128 \\
\hline $\begin{array}{l}\mathrm{C}-\mathrm{C}_{3} \\
\mathrm{C}_{3}-3\end{array}$ & $\begin{array}{l}754 \\
861 \\
\end{array}$ & $\begin{array}{r}596 \\
861 \\
\end{array}$ & $\begin{array}{l}0.92 \\
0.65 \\
\end{array}$ & $\begin{array}{l}5.51 \\
5.62 \\
\end{array}$ & & $\begin{array}{l}0.74 \\
0.75 \\
\end{array}$ & $\begin{array}{r}80 \\
115 \\
\end{array}$ & \\
\hline Total & $\overline{1615}$ & $\overline{1457}$ & $\overline{0.77}$ & $\overline{11.13}$ & 13,400 & 1.49 & $\overline{195}$ & 131 \\
\hline $\begin{array}{l}\mathrm{D}-\mathrm{D}_{4} \\
\mathrm{D}_{4}-4\end{array}$ & $\begin{array}{l}1260 \\
1581 \\
\end{array}$ & $\begin{array}{l}673 \\
655 \\
\end{array}$ & $\begin{array}{l}0.76 \\
1.73\end{array}$ & $\begin{array}{r}5.10 \\
11.32\end{array}$ & & $\begin{array}{l}0.46 \\
1.03\end{array}$ & $\begin{array}{l}61 \\
60\end{array}$ & \\
\hline Total & 2841 & $\overline{1328}$ & $\overline{1.24}$ & $\overline{16.42}$ & 9,100 & 1.49 & 121 & 81 \\
\hline
\end{tabular}

a-Non-tidal drift from Coast and Geodetic Survey Observations, Marmer (1935).

\section{TABLE XIV}

Fresh Water Transport Through Various Sections off New York, APRIL, 1948. RIVER FLOW $=1.49 \times 10^{\circ} \mathrm{ft}^{3} /$ day.

\begin{tabular}{|c|c|c|c|c|c|c|c|c|}
\hline Section & $\begin{array}{l}\text { Area of } \\
\text { Section } \\
10^{4} \mathrm{ft}^{2}\end{array}$ & $\begin{array}{c}\text { Freshened } \\
\text { Area } \\
10^{4} \mathrm{ft}^{2}\end{array}$ & $\begin{array}{c}\text { Fresh } \\
\text { Water } \\
\%\end{array}$ & $\begin{array}{l}\text { Area } \\
\text { Fresh } \\
10^{4} \mathrm{ft}^{2}\end{array}$ & $\begin{array}{r}\text { Net } \\
\text { Drift } \\
\mathrm{ft} / \text { day }\end{array}$ & $\begin{array}{r}\text { Tra } \\
10^{0} f \\
\text { Fresh }\end{array}$ & $\begin{array}{l}\text { ort } \\
\text { day } \\
\text { Total }\end{array}$ & $\begin{array}{c}\text { Relative } \\
\text { Volumes } \\
\text { Total/fresh }\end{array}$ \\
\hline $\begin{array}{l}A_{-} A_{1} \\
A_{1-1}\end{array}$ & $\begin{array}{r}37 \\
133 \\
\end{array}$ & $\begin{array}{r}37 \\
133 \\
\end{array}$ & $\begin{array}{l}12.8 \\
12.0\end{array}$ & $\begin{array}{r}4.75 \\
15.96 \\
\end{array}$ & $\begin{array}{l}26,300 a \\
17,800\end{array}$ & $\begin{array}{l}1.26 \\
2.84 \\
\end{array}$ & $\begin{array}{l}10 \\
24 \\
\end{array}$ & \\
\hline Total & 170 & 170 & 12.2 & 20.71 & & 4.10 & 34 & 8.3 \\
\hline $\begin{array}{l}\mathrm{B}-\mathrm{B}_{2} \\
\mathrm{~B}_{2}-2\end{array}$ & $\begin{array}{l}385 \\
628 \\
\end{array}$ & $\begin{array}{l}289 \\
238 \\
\end{array}$ & $\begin{array}{l}4.00 \\
4.77 \\
\end{array}$ & $\begin{array}{l}11.56 \\
11.35 \\
\end{array}$ & & $\begin{array}{l}2.07 \\
2.03 \\
\end{array}$ & $\begin{array}{l}52 \\
43 \\
\end{array}$ & \\
\hline Total & 1013 & 527 & 4.35 & 22.91 & 17,900 & 4.10 & 95 & 23 \\
\hline $\begin{array}{l}\mathrm{C}-\mathrm{C}_{3} \\
\mathrm{C}_{3}-3\end{array}$ & $\begin{array}{l}966 \\
768 \\
\end{array}$ & $\begin{array}{l}656 \\
518 \\
\end{array}$ & $\begin{array}{l}2.56 \\
1.34 \\
\end{array}$ & $\begin{array}{r}16.78 \\
6.95 \\
\end{array}$ & & $\begin{array}{l}2.90 \\
1.20 \\
\end{array}$ & $\begin{array}{r}113 \\
90 \\
\end{array}$ & \\
\hline Total & 1734 & 1174 & 2.02 & 23.73 & 17,300 & 4.10 & 203 & 50 \\
\hline $\begin{array}{l}\text { D-D } \\
\text { D-4 }\end{array}$ & $\begin{array}{l}1893 \\
1526 \\
\end{array}$ & $\begin{array}{r}692 \\
142 \\
\end{array}$ & $\begin{array}{l}2.48 \\
0.44 \\
\end{array}$ & $\begin{array}{r}17.14 \\
0.63 \\
\end{array}$ & & $\begin{array}{l}3.96 \\
0.14 \\
\end{array}$ & $\begin{array}{r}160 \\
33 \\
\end{array}$ & \\
\hline Total & 3419 & 834 & 2.13 & 17.77 & 23,100 & 4.10 & 193 & 47 \\
\hline
\end{tabular}




\section{TABLE XV}

Fresh Water Transport Through Various SeCtions ofF New York, JULY, 1948. RIVER FLOW $=1.30 \times 10^{\circ} \mathrm{ft}^{3} /$ day.

\begin{tabular}{|c|c|c|c|c|c|c|c|c|}
\hline Section & $\begin{array}{l}\text { Area of } \\
\text { Section } \\
10^{4} \mathrm{ft}^{2}\end{array}$ & $\begin{array}{c}\text { Freshened } \\
\text { Area } \\
10^{1} \mathrm{ft}^{2}\end{array}$ & $\begin{array}{l}\text { Fresh } \\
\text { Water } \\
\%\end{array}$ & $\begin{array}{l}\text { Area } \\
\text { Fresh } \\
10^{4} \mathrm{ft}^{2}\end{array}$ & $\begin{array}{c}\text { Net } \\
\text { Drift } \\
\text { ft/day }\end{array}$ & $\begin{array}{r}\text { Tran } \\
10^{\circ} \mathrm{ft} \\
\text { Fresh }\end{array}$ & $\begin{array}{l}\text { ort } \\
\text { day } \\
\text { Total }\end{array}$ & $\begin{array}{c}\text { Relative } \\
\text { Volumes } \\
\text { Total/fresh }\end{array}$ \\
\hline $\begin{array}{l}A-A_{1} \\
A_{1-1}\end{array}$ & $\begin{array}{r}48 \\
147 \\
\end{array}$ & $\begin{array}{r}48 \\
123 \\
\end{array}$ & $\begin{array}{l}5.17 \\
5.19 \\
\end{array}$ & $\begin{array}{l}2.48 \\
6.38 \\
\end{array}$ & $\begin{array}{c}27,000 a \\
9,900\end{array}$ & $\begin{array}{l}0.67 \\
0.63 \\
\end{array}$ & $\begin{array}{l}13 \\
12 \\
\end{array}$ & \\
\hline Total & 195 & 171 & 5.18 & 8.86 & & 1.30 & 25 & 19 \\
\hline $\begin{array}{l}\mathrm{B}-\mathrm{B}_{3} \\
\mathrm{~B}_{3}-2\end{array}$ & $\begin{array}{l}415 \\
730 \\
\end{array}$ & $\begin{array}{l}131 \\
258 \\
\end{array}$ & $\begin{array}{l}1.29 \\
3.54\end{array}$ & $\begin{array}{l}1.69 \\
9.14\end{array}$ & & $\begin{array}{l}0.20 \\
1.10\end{array}$ & $\begin{array}{l}16 \\
31\end{array}$ & \\
\hline Total & 1145 & 389 & 2.79 & 10.83 & 12,000 & 1.30 & 47 & 36 \\
\hline $\begin{array}{l}\mathrm{C}-\mathrm{C}_{3} \\
\mathrm{C}_{8}-3\end{array}$ & $\begin{array}{r}1003 \\
814 \\
\end{array}$ & $\begin{array}{l}293 \\
331 \\
\end{array}$ & $\begin{array}{l}1.25 \\
1.37 \\
\end{array}$ & $\begin{array}{l}3.67 \\
4.55 \\
\end{array}$ & & $\begin{array}{l}0.58 \\
0.72 \\
\end{array}$ & $\begin{array}{l}46 \\
52 \\
\end{array}$ & \\
\hline Total & 1817 & 624 & 1.32 & 8.22 & 15,800 & 1.30 & 98 & 75 \\
\hline $\begin{array}{l}D-D_{4} \\
D_{4}-4\end{array}$ & $\begin{array}{l}1832 \\
1459 \\
\end{array}$ & $\begin{array}{l}175 \\
381 \\
\end{array}$ & $\begin{array}{l}0.39 \\
1.49 \\
\end{array}$ & $\begin{array}{l}0.69 \\
5.66\end{array}$ & & $\begin{array}{l}0.14 \\
1.16\end{array}$ & $\begin{array}{l}36 \\
78\end{array}$ & \\
\hline Total & 3291 & 556 & 1.14 & 6.35 & 20,500 & 1.30 & 114 & 88 \\
\hline
\end{tabular}

\section{TABLE XVI}

Fresh Water Transport Through Various Sections off New York, OCTOBER, 1948. RIVER FLOW $=0.60 \times 10^{\circ} \mathrm{ft}^{8} /$ day.

\begin{tabular}{|c|c|c|c|c|c|c|c|c|}
\hline Section & $\begin{array}{l}\text { Area of } \\
\text { Section } \\
10^{4} \mathrm{ft}^{2}\end{array}$ & $\begin{array}{c}\text { Freshened } \\
\text { Area } \\
10^{1} \mathrm{ft}^{2}\end{array}$ & $\begin{array}{l}\text { Fresh } \\
\text { Water } \\
\%\end{array}$ & $\begin{array}{l}\text { Area } \\
\text { Fresh } \\
10^{1} \mathrm{ft}^{2}\end{array}$ & $\begin{array}{c}\text { Net } \\
\text { Drift } \\
\mathrm{ft} / \text { day }\end{array}$ & $\begin{array}{r}\text { Tran } \\
10^{\circ} \mathrm{ft} \\
\text { Fresh }\end{array}$ & $\begin{array}{l}\text { ort } \\
\text { day } \\
\text { Total }\end{array}$ & $\begin{array}{c}\text { Relative } \\
\text { Volumes } \\
\text { Total/fresh }\end{array}$ \\
\hline $\begin{array}{l}A-A_{1} \\
A_{1-1}\end{array}$ & $\begin{array}{r}53 \\
218 \\
\end{array}$ & $\begin{array}{r}53 \\
218 \\
\end{array}$ & $\begin{array}{l}4.83 \\
1.01 \\
\end{array}$ & $\begin{array}{l}2.56 \\
2.20\end{array}$ & & $\begin{array}{l}0.32 \\
0.28\end{array}$ & $\begin{array}{r}7 \\
27\end{array}$ & \\
\hline Total & 271 & 271 & 1.76 & 4.76 & 12,600 & $\overline{0.60}$ & $\overline{34}$ & 57 \\
\hline $\begin{array}{l}\mathrm{B}-\mathrm{B}_{3} \\
\mathrm{~B}_{3}-3\end{array}$ & $\begin{array}{l}846 \\
545 \\
\end{array}$ & $\begin{array}{l}813 \\
545 \\
\end{array}$ & $\begin{array}{l}0.52 \\
0.61\end{array}$ & $\begin{array}{l}4.22 \\
3.35\end{array}$ & & $\begin{array}{l}0.33 \\
0.27\end{array}$ & $\begin{array}{l}64 \\
43\end{array}$ & \\
\hline Total & 1391 & 1358 & 0.56 & 7.57 & 7,930 & 0.60 & 107 & 179 \\
\hline $\begin{array}{l}\text { C-C } 4 \\
\mathrm{C}_{4}-4\end{array}$ & $\begin{array}{l}1466 \\
1018\end{array}$ & $\begin{array}{l}670 \\
136 \\
\end{array}$ & $\begin{array}{l}0.57 \\
0.40 \\
\end{array}$ & $\begin{array}{r}3.80 \\
0.55 \\
\end{array}$ & & $\begin{array}{l}0.52 \\
0.08 \\
\end{array}$ & $\begin{array}{l}92 \\
19 \\
\end{array}$ & \\
\hline Total & 2484 & 806 & 0.54 & 4.35 & 13,800 & 0.60 & 111 & 185 \\
\hline
\end{tabular}




\section{TABLE XVII}

Fresh Water Transport Through Various Sections off New York, AUgusT, 1949. River FLOW $=0.46 \times 10^{\circ} \mathrm{ft}^{3} /$ day.

\begin{tabular}{|c|c|c|c|c|c|c|c|c|}
\hline Section & $\begin{array}{r}\text { Area of } \\
\text { Section } \\
10^{4} \mathrm{ft}^{2}\end{array}$ & $\begin{array}{c}\text { Freshened } \\
\text { Area } \\
10^{4} \mathrm{ft}^{2}\end{array}$ & $\begin{array}{l}\text { Fresh } \\
\text { Water } \\
\%\end{array}$ & $\begin{array}{l}\text { Area } \\
\text { Fresh } \\
10^{1} \mathrm{ft}^{2}\end{array}$ & $\begin{array}{c}\text { Net } \\
\text { Drift } \\
\mathrm{ft} / \text { day }\end{array}$ & $\begin{array}{l}\text { Tran } \\
10^{\circ} \mathrm{ft}^{2} \\
\text { Fresh }\end{array}$ & $\begin{array}{l}\text { dart } \\
\text { day } \\
\text { Total }\end{array}$ & $\begin{array}{l}\text { Relative } \\
\text { Volumes } \\
\text { Total/fresh }\end{array}$ \\
\hline $\begin{array}{l}A-A_{1} \\
A_{x}-1\end{array}$ & $\begin{array}{r}57 \\
182 \\
\end{array}$ & $\begin{array}{r}52 \\
182 \\
\end{array}$ & $\begin{array}{l}6.31 \\
2.26 \\
\end{array}$ & $\begin{array}{l}3.28 \\
4.12\end{array}$ & & $\begin{array}{l}0.204 \\
0.256\end{array}$ & $\begin{array}{r}3.2 \\
11.3\end{array}$ & \\
\hline Total & 239 & 234 & 3.16 & 7.40 & 6,220 & 0.460 & 14.5 & 32 \\
\hline $\begin{array}{l}\text { B-B } 2 \\
\text { B }_{2-2}\end{array}$ & $\begin{array}{l}362 \\
733\end{array}$ & $\begin{array}{r}178 \\
26\end{array}$ & $\begin{array}{l}0.66 \\
0.08\end{array}$ & $\begin{array}{l}1.18 \\
0.02\end{array}$ & & $\begin{array}{l}0.452 \\
0.008\end{array}$ & $\begin{array}{l}68 \\
10\end{array}$ & \\
\hline Total & 1095 & 204 & 0.59 & 1.20 & 38,300 & 0.460 & 78 & 170 \\
\hline $\begin{array}{l}\text { C-C. } \\
\mathrm{C}_{8-3}\end{array}$ & $\begin{array}{l}882 \\
844\end{array}$ & $\begin{array}{r}185 \\
59\end{array}$ & $\begin{array}{l}2.04 \\
0.32\end{array}$ & $\begin{array}{l}3.78 \\
0.19\end{array}$ & & $\begin{array}{l}0.438 \\
0.022\end{array}$ & $\begin{array}{r}21 \\
7\end{array}$ & \\
\hline Total & $\overline{1726}$ & $\overline{244}$ & $\overline{1.63}$ & $\overline{3.97}$ & 11,600 & $\overline{0.460}$ & $\overline{28}$ & 61 \\
\hline $\begin{array}{l}\text { D-D } \\
\text { D:-4 }\end{array}$ & $\begin{array}{r}1887 \\
1408 \\
\end{array}$ & $\begin{array}{l}262 \\
115 \\
\end{array}$ & $\begin{array}{l}0.57 \\
0.16 \\
\end{array}$ & $\begin{array}{l}1.50 \\
0.18 \\
\end{array}$ & & $\begin{array}{l}0.410 \\
0.050 \\
\end{array}$ & $\begin{array}{l}72 \\
31 \\
\end{array}$ & \\
\hline Total & 3295 & 377 & 0.45 & 1.68 & 27,400 & 0.460 & 103 & 224 \\
\hline
\end{tabular}

TABLE XVIII

Fresh Water Transport Through Various Sections off New York, JANUARY, 1950. RIVER FLOW $=2.51 \times 10^{\circ} \mathrm{ft}^{8} /$ day.

\begin{tabular}{|c|c|c|c|c|c|c|c|c|}
\hline Section & $\begin{array}{c}\text { Area of } \\
\text { Section } \\
10^{4} \mathrm{ft}^{2}\end{array}$ & $\begin{array}{c}\text { Freshened } \\
\text { Area } \\
10^{4} \mathrm{ft}^{2}\end{array}$ & $\begin{array}{c}\text { Fresh } \\
\text { Water } \\
\%\end{array}$ & $\begin{array}{l}\text { Area } \\
\text { Fresh } \\
10^{4} \mathrm{ft}^{2}\end{array}$ & $\begin{array}{l}\text { Net } \\
\text { Drift } \\
\mathrm{ft} / \text { day }\end{array}$ & $\begin{array}{l}\text { Tran } \\
10^{\theta} \mathrm{ft} \\
\text { Fresh }\end{array}$ & $\begin{array}{l}\text { dayt } \\
\text { Total }\end{array}$ & $\begin{array}{l}\text { Relative } \\
\text { Volumes } \\
\text { Total/fresh }\end{array}$ \\
\hline $\begin{array}{l}A-A x \\
A x-1\end{array}$ & $\begin{array}{r}53 \\
151 \\
\end{array}$ & $\begin{array}{r}50 \\
127 \\
\end{array}$ & $\begin{array}{l}9.76 \\
6.28 \\
\end{array}$ & $\begin{array}{l}4.88 \\
7.98 \\
\end{array}$ & $\begin{array}{l}26,300 a \\
15,400\end{array}$ & $\begin{array}{l}1.28 \\
1.23\end{array}$ & $\begin{array}{l}13 \\
20\end{array}$ & \\
\hline Total & .204 & 177 & 7.27 & 12.86 & & 2.51 & $\overline{33}$ & 13 \\
\hline $\begin{array}{l}\mathrm{B}-\mathrm{B}_{2} \\
\mathrm{~B}_{2}-2\end{array}$ & $\begin{array}{l}308 \\
650 \\
\end{array}$ & $\begin{array}{l}193 \\
271 \\
\end{array}$ & $\begin{array}{l}3.96 \\
2.30 \\
\end{array}$ & $\begin{array}{l}7.64 \\
6.22 \\
\end{array}$ & & $\begin{array}{l}1.38 \\
1.13 \\
\end{array}$ & $\begin{array}{l}35 \\
49 \\
\end{array}$ & \\
\hline Total & 958 & 464 & 2.99 & 13.86 & 18,100 & 2.51 & $\overline{84}$ & 33 \\
\hline $\begin{array}{l}\mathrm{C}-\mathrm{C} 3 \\
\mathrm{C}-3\end{array}$ & $\begin{array}{r}1107 \\
658 \\
\end{array}$ & $\begin{array}{r}98 \\
420 \\
\end{array}$ & $\begin{array}{l}2.80 \\
1.81 \\
\end{array}$ & $\begin{array}{l}7.62 \\
2.74 \\
\end{array}$ & & $\begin{array}{l}0.664 \\
1.846 \\
\end{array}$ & $\begin{array}{r}24 \\
102 \\
\end{array}$ & \\
\hline Total & 1765 & 518 & 2.00 & 10.36 & 24,200 & 2.510 & 126 & 50 \\
\hline $\begin{array}{l}\text { D-D } \\
\text { D }-4\end{array}$ & $\begin{array}{l}1542 \\
1805 \\
\end{array}$ & $\begin{array}{r}99 \\
848 \\
\end{array}$ & $\begin{array}{l}3.21 \\
1.32 \\
\end{array}$ & $\begin{array}{r}3.18 \\
11.23 \\
\end{array}$ & & $\begin{array}{l}0.554 \\
1.956 \\
\end{array}$ & $\begin{array}{r}17 \\
148 \\
\end{array}$ & \\
\hline Total & 3347 & 947 & 1.52 & 14.41 & 17,400 & 2.510 & 165 & 66 \\
\hline
\end{tabular}

a-Non-tidal drift from Coast and Geodetic Survey Observations, Marmer (1935). 
As one goes seaward from the mouth of the river the length and the area of the cross sections increases, which would permit the same volume of fresh water to be carried by slower flows. The volume of sea water entrained, however, increases, and the total volume of water moving seaward is greatly augmented. This tends to increase the rate of seaward drift. In most cases, these opposed factors interact so that, for each cruise, there was generally little difference in the velocity of non-tidal drift through the various sections.

The non-tidal drifts computed for the innermost section varied from 6210 to 26,700 feet per day (i.e., from 0.04 to 0.28 knots). For comparison, Marmer (1935) reports nontidal currents at Scotland Lightship (our station A-1) which averaged 0.18 to 0.19 knots. At Ambrose Lightship Marmer's average values were 0.09 to 0.11 knots. These values are of the same order of magnitude as the net drifts computed from the transport of fresh water. Our net drifts are averaged for the entire section, and would be greater in the region of greater transport of fresh water. The distribution of salinity makes it clear that in the Section A-A $A_{1}$, which terminated at Scotland Lightship, a large proportion of the transport was southerly. The appropriate value for the non-tidal currents, given by Marmer, has been used in computing the southerly transport of fresh water at Scotland Lightship. The easterly velocity was then computed so that the remainder of the fresh water would be transported through Section $A_{1}-1$. In October, 1948, and August, 1949, however, the values given by Marmer would carry more fresh water southward than was provided by the river flow. The average value, computed for the entire section, has been used exclusively for these cruises.

The volume of sea water entrained in the outflow crossing the innermost section varied from 14.5 to $60 \times 10^{9}$ cubic feet per day. The ratio between the total seaward flow and the river flow varied from about 8 in April, when the river flow was large, to 57 in August, 1949, when the river flow was small. There was not, however, any direct correlation between the volume of river flow and the volume of entrained sea water. This lack of direct correlation might be expected as a result of the varying distribution patterns.

As the water moves seaward it entrains progressively greater amounts of sea water, so that on the outskirts of the area surveyed the total flow is from 47 to 224 times as great as the river flow. The smaller ratio was found when the river flow was greatest; the larger was associated with minimum river flow. In this outermost section the relationship between entrained sea water and river flow is more direct.

The ratio of total flow to river flow is a measure of the magnitude of the oceanic counter current, since, in order to maintain the steady state distribution, the net exchange of salt across any complete cross section must be zero. The data show that, at all times, the volume of water in the counter drift was many times greater than the volume of river water.

\section{ACCUMULATION OF IRON}

The quantity of iron contributed to the surveyed area by the river flow, and by the discharge of acid-iron wastes at sea has been estimated at various times. The comparison of these values with the total amount of iron within the area gives another estimate of the average rate at which the water is replaced by the circulation.

The quantity of iron contributed by the rivers has been estimated in two ways: the section method, in which the average concentration of iron in a complete cross section is multiplied by the total water transport across the section; and the river contribution method, in which the average concentration of iron in the river water is multiplied by 


\section{TABLE XIX}

\section{Daily Contribution of Iron to the Offshore ARea by River EfFluents}

Date

Feb., 1948

April, 1948

July, 1948

Oct., 1948

Aug., 1949

Jan., 1950
Basis of Computations

Section Sandy Hook-Far Rockaway

Section A, Sandy Hook-Scotland Lightship-Long Island

Average

Section A, Sandy Hook-Scotland Lightship-

Long Island

Section A, Sandy Hook-Scotland Lightship_-Long Island Contribution Raritan River

Hudson River
Tons $\mathrm{Fe} /$ day

40

65

52.5

112

47

$\underset{\text { Average }}{\frac{29}{51}}$

Section Sandy Hook-Far Rockaway 55

Section A, Sandy Hook-Scotland Lightship-Long Island

Average

Section A, Sandy Hook-Scotland Lightship-Long Island

15

Section A, Sandy Hook-Scotland Lightship-Long Island

the river flow. The results of these computations are shown in Table XIX. Comparison of the two methods of estimation are afforded by the July data in which the section method gave a value of 47 tons/day and the river contribution method indicated a total of 55 tons/day.

The total quantity of iron entering the area in the river effluent was about 50 tons per day, except in April, 1948, and in August, 1949. In April the daily quantity was twice as great, an increase which was associated with the large river flow which may have stirred up sedimented iron from the river bottom. The August contribution was only 15 tons per day. This low value was associated with the minimum runoff observed in August.

Starting at the end of April, 1948, acid-iron wastes were dumped at sea within this area by 'The National Lead Company. Between July and October they barged and dumped at sea daily about 60 tons of iron, as ferrous sulphate. After November, 1948, the dailv contributions increased to about 80 tons. This value has been added to the daily river contributions to obtain an estimate of the total rate of supply.

The total quantity of iron accumulated within the area has been estimated by calculating the average concentration of iron at each station. The total volume of water in each segment of the grid was multiplied by the average of the concentrations of iron in the surrounding stations, due allowance being made for differences in depth. If it is assumed that pure, uncontaminated sea water contains no iron, within the accuracy of analysis, the quantity of iron accumulated can be attributed solely to pollution.

The ratio of the quantity of iron accumulated within the area to the daily increment gives the number of days required to flush the iron contaminated water through the area. The results are shown in Table XX, where the flushing times computed from both the iron and the fresh water transport are compared. 
The times required to flush the area, computed from the accumulation and daily increment of iron, range from 8.3 to 13.9 days. This is in substantial agreement with the 6.0 to 10.6 days computed from the fresh water transport.

\section{TABLE XX}

COMPARISON OF IRON ENTERING NeW YORK BIGHT AREA AND TOTAL ACCUMUl.aTION WITHIN ·AREA

$\begin{array}{lcccccc}\text { Date } & \begin{array}{c}\text { Surface } \\ \text { Area } \\ \text { sq. miles }\end{array} & \begin{array}{c}\text { Iron Contributions } \\ \text { River flow } \\ \text { tons/day }\end{array} & \begin{array}{c}\text { Dumped at Sea } \\ \text { tons/day }\end{array} & \begin{array}{c}\text { Iron } \\ \text { Accumulated } \\ \text { tons }\end{array} & \begin{array}{r}\text { Time to Flush } \\ \text { Iron } \\ \text { days }\end{array} & \begin{array}{c}\text { Fr. Water } \\ \text { days }\end{array} \\ \text { Feb., 1948 } & 483 & 52.5 & & 552 & 10.5 & 6.0 \\ \text { April, 1948 } & 662 & 112 . & & 896 & 8.0 & 7.4 \\ \text { July, 1948 } & 683 & 51 . & 60 & 1350 & 12.2 & 9.7 \\ \text { Oct., 1948 } & 476 & 57.5 & 60 & 1436 & 12.2 & 10.6 \\ \text { Aug., 1949 } & 628 & 15 . & 80 & 1107 & 11.7 & 7.9 \\ \text { Jan., 1950 } & 650 & 49.5 & 80 & 1807 & 13.9 & 6.3\end{array}$

\section{DISCUSSION OF WATER TRANSPORT}

The observation that only six to ten days are required, on the average, to flush the river effluents through the surveyed part of the New York Bight, shows that there is an active circulation within the area. This rapid flushing has obvious implications in connection with the dispersal of pollutants and helps to explain why there is no great accumulation of the pollution which is contributed daily in large quantities in the river effluents.

The flushing rate of the New York Bight was found to be independent of the rate of river flow. Although the river flow varied nearly ninefold, the maximum variation in flushing time was less than twofold. The effect of increasing river flow was to increase the concentration, and thus the total accumulation, of river water included within any part of the area. The observation that the rate of flushing of the Bight was independent of the volume of river flow is an important relationship, since it suggests that the tidal oscillations, which are also independent of river flow, are predominantly important in the flushing of such regions.

It is of interest to compare the volume of water provided by river flow with the total volume of water included in the surveyed area. These values aid in comprehending the relative size and importance of the river drainage in this area. The total volume of water in the surveyed area ranged from 500 to 2000 times as great as the daily river flow. The total volume of water contributed by the rivers during 1948 was 729 billion cubic feet. This is about $40 \%$ of the volume of water in the surveyed area, and it would thus take more than $21 / 2$ years for the river flow to replace the volume of water present. Since it has been shown that only 6 to 10 days' contribution of the rivers was accumulated at any time, it is clear that the oceanic contribution to the circulation in this area was many times greater than the river water contribution. The estimates showed that the volume of the oceanic counter drift entering the outer boundary of the surveyed area ranged from 47 to 224 times as great as the volume of river flow. The rapid flushing of the area may be directly ascribed to the large volume of the oceanic circulation. 
The computation of the flushing rate based upon the accumulation of iron was in substantial agreement with the flushing rate computed from the fresh water transport. In every case, however, the estimate based on iron gave a somewhat greater time than the estimate based on fresh water transport, and it is of interest to speculate on possible explanations. First, it should be emphasized that these results suggest that the amount of iron settling to the bottom, and thus removed from the water, must be small-otherwise the time required to flush the iron would appear to be shorter than the time required to flush the fresh water.

In making these calculations it was assumed that the iron content of pure sea water was zero, and on many of the cruises water containing no measurable iron was observed. The method used measured all of the reducible iron in solution or in suspension in the water. Analyses for very small quantities were, however, complicated by the turbidity of the water, which was measured after acidification of the sample, but before the addition of dipyridyl which develops the color used in the determination. The turbidity introduces an uncertainty in the analysis of low concentrations. The method used, furthermore, does not measure iron in organic combination, and during periods of active plankton growth much of the iron may be so combined. Sverdrup, Johnson and Fleming (1942) list the concentration of iron in sea water as 2 to $20 \mu \mathrm{g}$ per kilogram of solution. Taking the smaller concentration as representing the concentration to be expected in uncontaminated sea water, the quantity of iron from this source within the surveyed area would range from about 80 to 120 tons. If these quantities were deducted from the estimate of accumulated iron the flushing times would be reduced by somewhat more than one day. They would thus be made more like the times estimated from river water transport.

Another mechanism may be postulated to explain the longer times required to flush the iron. The accumulation of iron would tend to be increased if some of the iron were to return to the area in the oceanic counter current. Such a mechanism is plausible, since the iron is in particulate form which will settle slowly, whereas the fresh water tends to accumulate at the surface. In April and July, 1948, and January, 1950, when the water was vertically stratified, the iron might be expected to settle through the thermocline and thus enter the counter drift of sea water. The flow would thus bring some of the iron back to be mixed with the surface layers again in the northwestern part of the area. At other times, when vertical stratification was not pronounced, the counter drift was horizontally separated from the seaward drift of freshened water, and the settling of iron would not be expected to produce the observed accumulations.

In conclusion, it may be reemphasized that, in spite of uncertainties in some of the methods of estimate, it is clear that the water circulation within this area is rapid. Not more than about ten days' contribution of any pollutant, dissolved or suspended in the water, will accumulate in the area at any one time. 


\section{SUMMARY}

1. Six cruises were made at different seasons to survey the hydrographic conditions in the inner part of the New York Bight, where the effluent from the Hudson and other rivers enters the sea. The distributions of salinity, temperature, oxygen and iron are described.

2. Sea water diluted with river. water varies greatly in distribution from the more common pattern with the diluted water confined to a natrow band along the New Jersey shore, to a pattern with the diluted sea water widely distributed over the surface.

3. On four of the six cruises, when the river flow was fairly great, the distribution patterns were well defined. Dynamic calculations indicated that the current velocities required to maintain these distributions in steady state were possible. Both widespread and confined patterns of distribution were included.

4. On the two cruises when the river flow was small, the distribution patterns were erratic and ill defined. It is concluded that, at these times, the assumption of a steady state was untenable, and that these patterns could be expected to change under the existing conditions.

5. Although it would take about $21 / 2$ years for the river flow to displace the water within the surveyed area, it is calculated that the average flushing time is 6 to 10 days. This is true in spite of almost ninefold variations in river flow. The volume of sea water involved in the circulation ranged from 47 to 224 times as great as the volume of river flow. It is concluded that the flushing of the region is independent of the river flow.

6. Flushing times computed from the accumulation of iron pollution were in substantial agreement with the times computed from the distribution of river water.

. 7. The active circulation and rapid flushing of this region helps to explain why there is no great accumulation of pollution which is contributed daily in large quantities in the river effluent. 


\section{REFERENCES}

Bigelow, H. B., 1933: Studies of the Waters on the Continental Shelf, Cape Cod to Chesapeake Bay. I. The Cycle of Temperature. Pap. Phys. Oceanogr. Meteorol. 2(4):135 pp.

Bigeiow, H. B., and M. SEARS, 1935: Studies of the Waters of the Continental Shelf, Cape Cod to Chesapeake Bay. II. Salinity. Pap. Pbys. Oceanogr. Meteorol. 4(1):94 pp.

COOPER, L. H. N., 1935: Iron in the Sea and in Marine Plankton. Proc. Roy. Soc., London, B, $118(810): 419-438$.

, 1937: Some Conditions Governing the Solubility of Iron. Proc. Roy. Soc., London, B, $124(836): 299-307$.

1 1948: The Distribution of Iron in the Waters of the Western English Channel. Jour. Mar. Biol. Assoc. 27 (2):279-313.

, 1948: Some Chemical Considerations on the Distribution of Iron in the Sea. Jour. Mar. Biol. Assoc. $27(2): 315-321$.

EkMaN, V. W., 1902: Om Jordrotationens Inverkan pa Vindstrommar i Hafet. Nyt Mag. Naturvid. 40:37-63.

FORD, W. L., 1949: The Field Use of a Salinity-Temperature-Depth Recorder. Jour. Mar. Res. $8(1): 84-96$

-1950: Seagoing Photoelectric Colorimeter. Anal. Chem. 22:1431-1435.

Great Britain, Department of Scientific ANd Industrial Research, 1931: Survey of the River Tees. I. Hydrographical. Water Pollution Res. Tech. Rept. No. 2:92 pp.

—_ 1935: Survey of the River Tees. II. The Estuary, Chemical and Biological. (By W. B. Alexander, B. A. Southgate, and R. Bassindale). Ibid. No. 5:171 pp.

HarTley, P. H. T., AND G. M. SpoOneR, 1938: The Ecology of the Tamar Estuary. I. Introduction. Jour. Mar. Biol. Assoc. 22:501-508.

Iselin, C. O'D., 1936: A Study of the Circulation of the Western North Atlantic. Pap. Pbys. Oceanogr. Meteorol. 4(4):101 pp.

, 1940: Preliminary Report on Long-Period Variations in the Transport of the Gulf Stream System. Pap. Phys. Oceanogr. Meteorol. 8(1):40 pp.

JACoBson, A. W., 1948: An Instrument for Recording Continuously the Salinity, Temperature, and Depth of Sea Water. Trans. Amer. Inst. Elec Eng. 67:714-722.

KALLE, K., 1939: Einige Verbesserungen zur Bestimmung des gelosten Sauerstoffs im Meerwasser. Ann. Hydrogr. 67:267-269.

MARMer, H. A., 1935: Tides and Currents in New York Harbor. U. S. Coast and Geodetic Survey, Spec. Publ. No. 111:vii +198 pp.

MILNE, A., 1938: The Ecology of the Tamar Estuary. III. Salinity and Temperature Conditions in the Lower Estuary. Jour. Mar. Biol. Assoc. 22:529-542.

OxNer, M., 1920: Chloruration par a Méthode de Knudsen. Bull. Comm. Int. Explor. Mer Méditerranée No. 3:36 pp.

Sverdrup, H. U., M. W. Johnson, and R. H. Fleming, 1942: The Oceans: Their Physics, Chemistry, and General Biology. New York, Prentice-Hall Inc. $x+1087$ pp.

Tully, J., 1949: Oceanography and Prediction of Pulp Mill Pollution in Alberni Inlet. Bull. Fish. Res. Bd., Canada, 83:169 pp. 